\title{
Weekly gridded Aquarius L-band radiometer/scatterometer observations and salinity retrievals over the polar regions - Part 2: Initial product analysis
}

\author{
L. Brucker ${ }^{1,2}$, E. P. Dinnat ${ }^{1,3}$, and L. S. Koenig ${ }^{1}$ \\ ${ }^{1}$ NASA GSFC, Cryospheric Sciences Laboratory, Code 615, Greenbelt, MD 20771, USA \\ ${ }^{2}$ Universities Space Research Association, Goddard Earth Sciences Technology and Research Studies and Investigations, \\ Columbia, MD 21044, USA \\ ${ }^{3}$ Chapman University, School of Earth and Environmental Sciences, Orange, CA 92866, USA
}

Correspondence to: L. Brucker (ludovic.brucker@nasa.gov)

Received: 25 November 2013 - Published in The Cryosphere Discuss.: 12 December 2013

Revised: 12 December 2013 - Accepted: 23 March 2014 - Published: 16 May 2014

\begin{abstract}
Following the development and availability of Aquarius weekly polar-gridded products, this study presents the spatial and temporal radiometer and scatterometer observations at $\mathrm{L}$ band (frequency $\sim 1.4 \mathrm{GHz}$ ) over the cryosphere including the Greenland and Antarctic ice sheets, sea ice in both hemispheres, and over sub-Arctic land for monitoring the soil freeze/thaw state. We provide multiple examples of scientific applications for the L-band data over the cryosphere. For example, we show that over the Greenland Ice Sheet, the unusual 2012 melt event lead to an L-band brightness temperature (TB) sustained decrease of $\sim 5 \mathrm{~K}$ at horizontal polarization. Over the Antarctic ice sheet, normalized radar cross section (NRCS) observations recorded during ascending and descending orbits are significantly different, highlighting the anisotropy of the ice cover. Over sub-Arctic land, both passive and active observations show distinct values depending on the soil physical state (freeze/thaw). Aquarius sea surface salinity (SSS) retrievals in the polar waters are also presented. SSS variations could serve as an indicator of fresh water input to the ocean from the cryosphere, however the presence of sea ice often contaminates the SSS retrievals, hindering the analysis. The weekly grided Aquarius L-band products used are distributed by the US Snow and Ice Data Center at http: //nsidc.org/data/aquarius/index.html, and show potential for cryospheric studies.
\end{abstract}

\section{Introduction}

Since August 2011 the Aquarius/SAC-D mission, developed collaboratively between the US National Aeronautics and Space Administration (NASA) and the Argentinian's space agency, Comisión Nacional de Actividades Espaciales (CONAE), has collected L-band (frequency $\sim 1.4 \mathrm{GHz}$ ) passive and active observations. The primary objective of these observations is to retrieve sea surface salinity (SSS), however, these L-band observations also enable us to monitor the cryosphere in the polar regions. L-band observations from the European Space Agency's Soil Moisture and Ocean Salinity (SMOS) mission, launched in October 2009, is used to monitor soil freeze/thaw state in sub-Arctic environments (e.g., Rautiainen et al., 2012), and either thin sea ice thickness (Kaleschke et al., 2010, 2012; Tian-Kunze et al., 2013; Huntemann et al., 2014) or snow depth on thick sea ice (Maaß et al., 2014). An analysis of Aquarius observations at Dome C (Antarctic plateau) revealed that in spite of the deep penetration of the L-band radiation, evolutions of the snow surface properties influence L-band observations. Large brightness temperature (TB) variations (of up to $2.5 \mathrm{~K}$ at horizontal polarization) were related to the effect of surface snow metamorphism (Brucker et al., 2014a). In addition to the radiometers, Aquarius operates a scatterometer which makes it possible to leverage coincident L-band active/passive observations.

Brucker et al. (2014b) developed weekly polar-gridded products of Aquarius TB and Normalized Radar Cross 
Section (NRCS) observations, and SSS retrievals. These products contain data recorded at latitudes higher than $50^{\circ}$, and are gridded on the Equal-Area Scalable Earth version 2.0 (EASE2.0) grid (Brodzik et al., 2012), with a grid cell resolution of $36 \mathrm{~km}$, and a temporal resolution of 7 days (corresponding to the spacecraft period of revisit). For full details on this product see Part 1 of this two-part article series (Brucker et al., 2014b).

This study aims at presenting maps and time series of the TB and NRCS weekly polar-gridded products, with a focus on the Greenland and Antarctic ice sheets, and sea ice in both hemispheres. Observations over land where frozen soil/permafrost may exist are presented, too. We also discuss maps of polar regions SSS and the effect of sea ice contamination. It is beyond the scope of this study to address the specifics in the data, and to relate quantitatively the remote sensing observations to geophysical properties. The products presented here enable these in-depth analyses for future research.

\section{Background on the weekly gridded products}

Aquarius operates three radiometers at $1.413 \mathrm{GHz}$ (at vertical $\mathrm{V}$ and horizontal $\mathrm{H}$ polarizations), with incidence angles of $29.2^{\circ}, 38.4^{\circ}$, and $46.3^{\circ}$. These radiometers are in a pushbroom alignment pointing to the right-hand side of the orbit. The largest spatial coverage of the Northern Hemisphere $(\mathrm{NH})$ is obtained using observations recorded at the highest incidence angle, whereas in the Southern Hemisphere (SH) it is obtained with observations at the lowest incidence angle. Hereinafter, we refer to radiometer 1,2 , and 3 as the incidence angle increases. The $3 \mathrm{~dB}$ footprint dimensions are $76 \mathrm{~km} \times 94 \mathrm{~km}, 84 \mathrm{~km} \times 120 \mathrm{~km}$, and $97 \mathrm{~km} \times 156 \mathrm{~km}$ (along $\times$ across track), for radiometer 1,2 , and 3, respectively. The radiometric sensitivity (per $1.44 \mathrm{~s}$ observation sample) is $\sim 0.15 \mathrm{~K}$ over the ocean (Le Vine et al., 2010). It increases to $\sim 0.2 \mathrm{~K}$ over higher emissivity surface such as that found over the Antarctic dry-snow zone (J. Piepmeier, personal communication, 2014).

Aquarius operates a scatterometer at $1.26 \mathrm{GHz}$ (at VV, $\mathrm{VH}$, and $\mathrm{HH}$ polarizations). The footprint sizes are slightly smaller than the radiometers'. The scatterometer calibration stability is within $0.1 \mathrm{~dB}$ (Yueh et al., 2012).

Radio frequency interference (RFI) contaminations do occur in Aquarius observations and depend on the orbit type (ascending vs. descending). Of note, Aquarius observations over the Greenland Ice Sheet (GIS) are less contaminated during ascending orbits (Brucker et al., 2014b). Over the Southern Ocean and Antarctic ice sheet (AIS), RFI contaminations are rare (Brucker et al., 2014b).

The Aquarius weekly polar-gridded products are described in detail in Brucker et al. (2014b). Briefly, for TB, each radiometer is treated independently to produce three weekly gridded TB products corresponding to observations from the ascending orbit, the descending orbit, and both orbit types combined. For each seven-day cycle, all valid observations from a given radiometer whose footprint center is within a given $36 \mathrm{~km}$ grid cell are averaged together, and the standard deviation is calculated. For NRCS, each beam and each orbit type is treated independently. For SSS, two weekly gridded products are available. The first SSS product provides the SSS corresponding to the weekly gridded TB: data are available separated per beam and per orbit type, and include combined ascending and descending orbits. The second SSS product is generated by combining the SSS retrieved from the three beams and both orbit types combined.

For each cycle, weekly average and standard deviation values are distributed. Products also include the number of footprint observations/retrievals within each grid cell. Where less than six contiguous grid cells do not have weekly averaged values, a Delaunay triangulation with linear interpolation was applied to spatially interpolate Aquarius data. The TB, NRCS, and SSS products are processed for every Aquarius cycle, and distributed in HDF5 format by the US Snow and Ice Data Center at http://nsidc.org/data/aquarius/index.html. Future release dates depend on the release of the Level 2 product, which is currently released monthly in a one month batch. We also provide ancillary files containing the grid cell center latitude and longitude, and the grid cell mean land fraction, as well as a look-up table to convert date to cycle number.

\section{L-band TB product analysis over the cryosphere}

Microwave observations are sensitive to snow properties, for example, liquid water content, grain size, density, temperature (Ulaby et al., 1986; Mäzler, 1987) and to their variations with depth (layering) (e.g, Zwally, 1977; Brucker et al., 2010, 2011). This sensitivity to snow properties has been used to monitor various geophysical properties over the ice sheets, such as snowmelt extent (e.g., Torinesi et al., 2003; Tedesco et al., 2007), snow accumulation (e.g., Abdalati and Steffen, 1998; Winebrenner et al., 2001), and grain size (Brucker et al., 2010; Picard et al., 2012).

At $\mathrm{L}$ band, the dielectric loss of the ice is uncertain and hence the penetration depth at this low-microwave frequency remains uncertain. However, the penetration depth of the L-band radiation is estimated at 1000 s of meters (Surdyk, 2002). Topographic variations within the Aquarius $3 \mathrm{~dB}$ footprint contribute to the L-band observations, and could, therefore, impact the retrievals of geophysical properties; evidences have been identified over North Africa and Australia (Utku and Le Vine, 2013). The interpretation of the L-band observations should thus be made with caution in areas with strong elevation change (e.g., due to bedrock elevation change). Due to the large-footprint dimensions, the interpretation of the L-band observations should also be made 


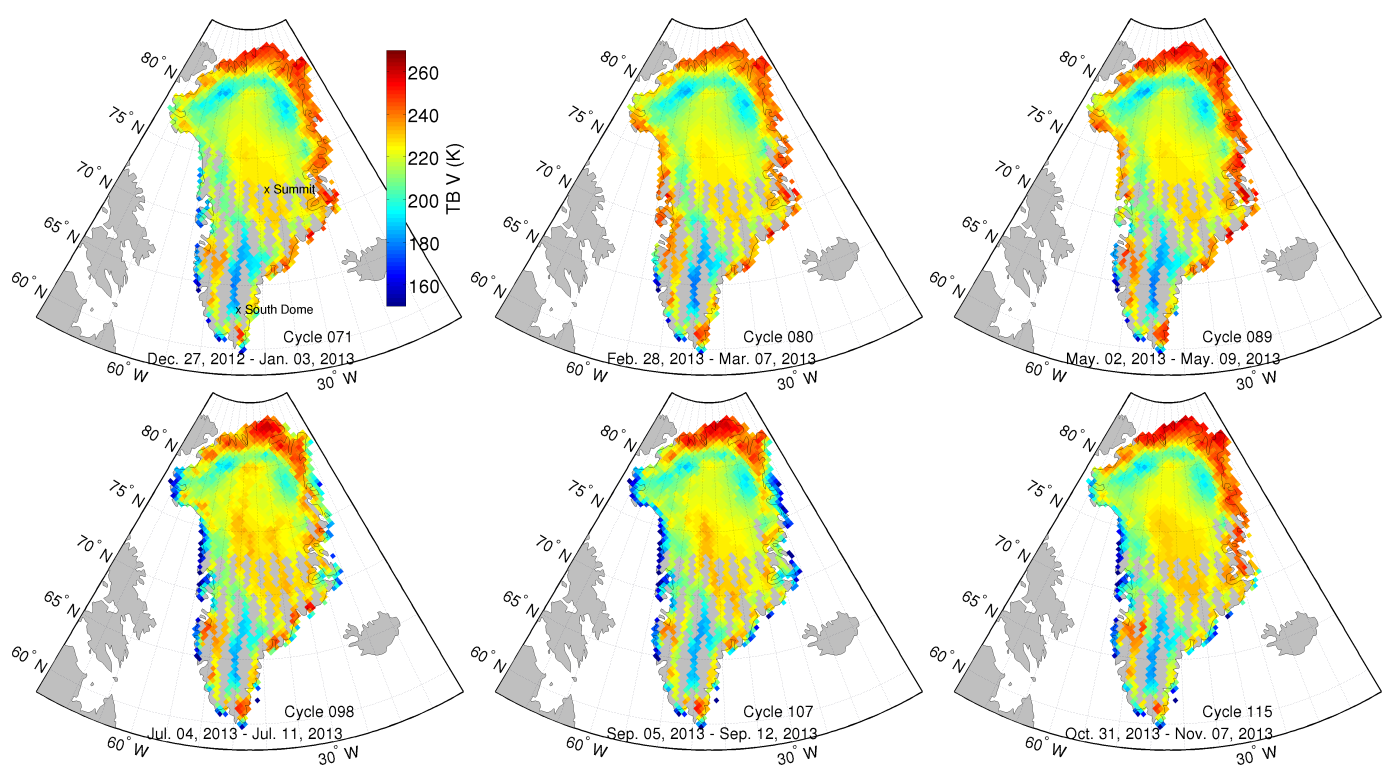

Fig. 1. Maps of TB (radiometer 3) at V polarization (in K) over the GIS every two months in 2013. Grid cells with land fraction less than 0.25 were masked.

with caution in coastal and mountainous areas, where multiple surface types may exist in the grid cells.

\subsection{The Greenland Ice Sheet (GIS)}

The weekly gridded product of L-band TB observations shows interesting spatial and temporal variations over the GIS (Fig. 1). Overall, TBs observed at $\mathrm{V}$ polarization with radiometer 3 are high $(>250 \mathrm{~K})$ year round in the northern coastal regions (extending up to $\sim 200 \mathrm{~km}$ inland), whereas the other coastal regions show a seasonal cycle with lower TBs in summer than in winter. This cycle directly results from the sea ice seasonal cycle, and the presence of open water in summer. Off the north and northeast Greenland coasts, sea ice is present year round, whereas it is not on the other Greenland coasts (see ice concentration maps in Brucker et al., 2014c).

Farther inland, TBs increase from $\sim 190$ to $\sim 230 \mathrm{~K}$ as elevation increases, and therefore as temperature, snow accumulation, and days of melting snow decrease. Inland (where snow is mostly dry), the lowest TBs are found year round in the central part of south Greenland at latitudes between $\sim 62$ and $\sim 68^{\circ} \mathrm{N}$ (radiometer 3 observations are $\sim 180 \mathrm{~K}$ at $\mathrm{V}$ polarization, Fig. 1). Additionally, at these latitudes there is a clear distinction between the eastern and western sides of the GIS, with systematically lower TBs on the eastern side. This difference comes from the different ice sheet properties. Southeast Greenland has the highest snow accumulation (Burgess et al., 2010), whereas southwest Greenland has lower snow accumulation and more melt; a large part of this region is in the ablation zone. Therefore, the L-band radiation emanates mainly from ice/firn/snow in southeast Greenland, and from ice/snow in southwest Greenland.

The weekly gridded product contains the standard deviations of TB observations made during the week in each grid cell. Over the GIS, standard deviations of TBs observed at V polarization by radiometer 3 during one cycle in winter are mostly less than $1 \mathrm{~K}$ (Fig. 2).

Distributions of the weekly gridded TB (radiometer 3) over the GIS for a cycle in January and July are similar at vertical polarization, and slightly change at horizontal polarization (Fig. 3). TBs have a range of about $180-260 \mathrm{~K}$ and $140-240 \mathrm{~K}$ at $\mathrm{V}$ and $\mathrm{H}$ polarizations, respectively. In summer, lower TBs exist at both polarizations, and they correspond to grid cells located in coastal regions where open water is present in the instrument field of view.

Using radiometer 1 , the time series of TB near South Dome (snow accumulation of $0.49 \mathrm{~m}$ w.e., Burgess et al., 2010), and near Summit (snow accumulation of $0.23 \mathrm{~m}$ w.e., Burgess et al., 2010) show that there is no annual cycle related to seasonal variations in the snow temperature profile (Fig. 4); see Fig. 1 for localization. However, observations in summer are impacted by snowmelt. Observations in the South Dome area show a sudden increase of TB (Fig. 4). Hourly air temperature measurements at the nearby weather station $\left(63.149^{\circ} \mathrm{N}, 44.817^{\circ} \mathrm{W}\right)$, part of the Greenland Climate Network (GC-net; Steffen et al., 1996), were above the melting point during that week (during 3 consecutive days for $12 \mathrm{~h}$ ). Thus, the sudden increase of TB is associated with the presence of liquid water in the snow cover. TBs remain high as long as measured air temperatures exceed $0^{\circ} \mathrm{C}$, maintaining the presence of liquid water. Later in the summer, TBs decrease as liquid water content decreases (freezes). This is 

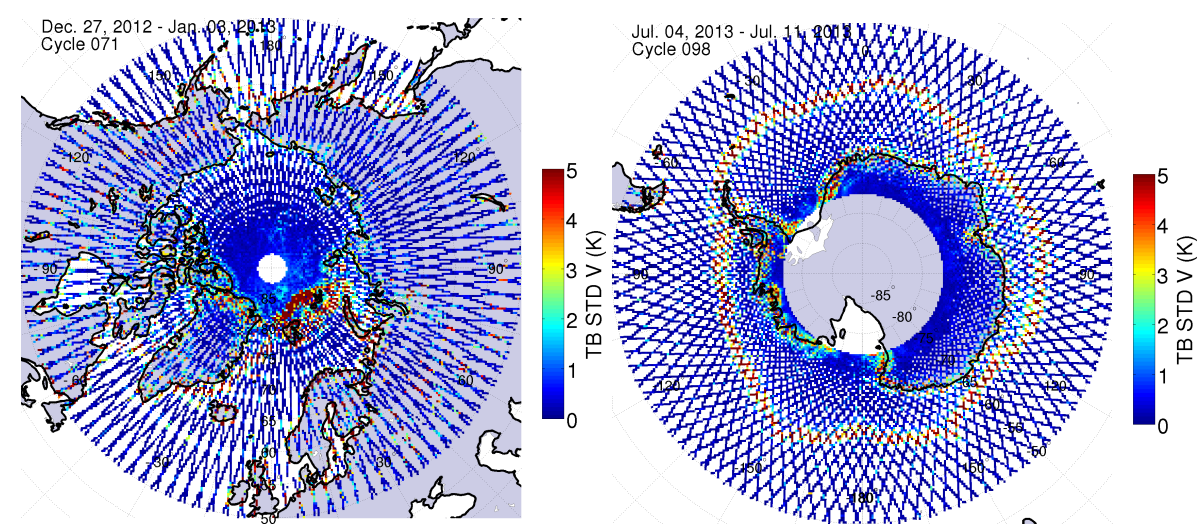

Fig. 2. Standard deviation of radiometer $3 \mathrm{~TB}$ V observations during (left) the cycle 71 over the NH and (right) the cycle 98 over the SH.
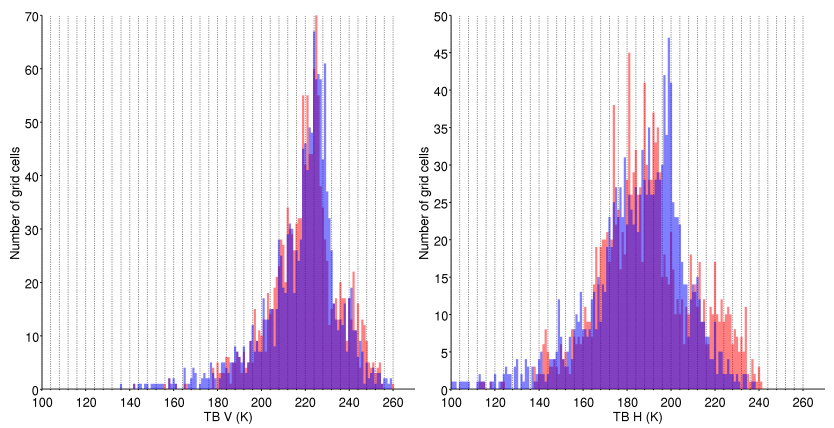

Fig. 3. Distributions of TB V (left) and TB H (right) observed over the GIS by radiometer 3 during the first week of January 2013 (red) and July 2013 (blue).

a TB evolution typical at microwave frequencies when snow is melting.

During the summer of 2012, unusual melt occurred over most of the GIS including Summit (Hall et al., 2013). During the period September 2011-September 2013, the mean $\mathrm{TB}$ at Summit was $222.9 \pm 3.2 \mathrm{~K}$ and $210.4 \pm 3.9 \mathrm{~K}$ at $\mathrm{V}$ and $\mathrm{H}$ polarization, respectively. Figure 4 also shows the TB observations at Summit during the summer 2012, and the time series of hourly air temperature measurements recorded by the Summit GC-net weather station $\left(72.579^{\circ} \mathrm{N}, 38.505^{\circ} \mathrm{W}\right)$. TBs started to increase by $\sim 8 \mathrm{~K}$ in late May 2012 , and suddenly dropped by more than 15 and $20 \mathrm{~K}$ at $\mathrm{V}$ and $\mathrm{H}$ polarizations, respectively. The drop occurred during the Aquarius cycle 47, 12-19 July 2012. Melt occurred at Summit during 4-5 days, ending on 14 July 2012 (Hall et al., 2013). An analysis of the swath data showed that the lowest TB was observed on July 11 . While melting snow has a highmicrowave emissivity implying high TB, Aquarius did not capture the high TBs at Summit characteristic of melting snow (Fig. 4). It is worth noting though that the TB level after the melt event is $\sim 5 \mathrm{~K}$ lower, revealing the significant impact of the recently formed near-surface refrozen snow layer on TB (Fig. 4). Even though the L-band radiation emanates from

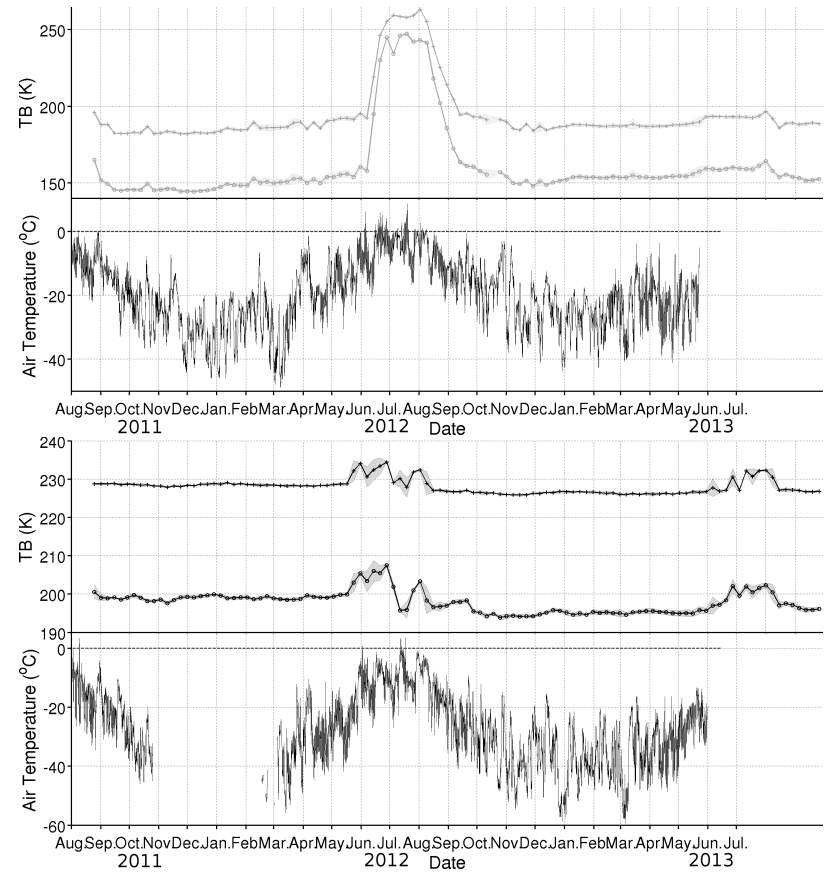

Fig. 4. Time series of $\mathrm{TB}$ (radiometer 1) at V (+) and $\mathrm{H}(\mathrm{o})$ polarizations, and GC-net air temperature measurements over South Dome (top two panels) and Summit (bottom two panels). The gray envelop corresponds to the weekly TB standard deviation.

deep in the ice sheet, surface reflection is an important process of the radiative transfer. It has been demonstrated that regions where melt occurs can bias snow accumulation retrievals using microwave TB (Magand et al., 2008), Fig. 4 shows that similar bias can be expected using L-band observations.

\subsection{The Antarctic ice sheet (AIS)}

AIS L-band TBs are characterized by low, stable TBs in the interior of the continent, and TBs varying seasonally on the 


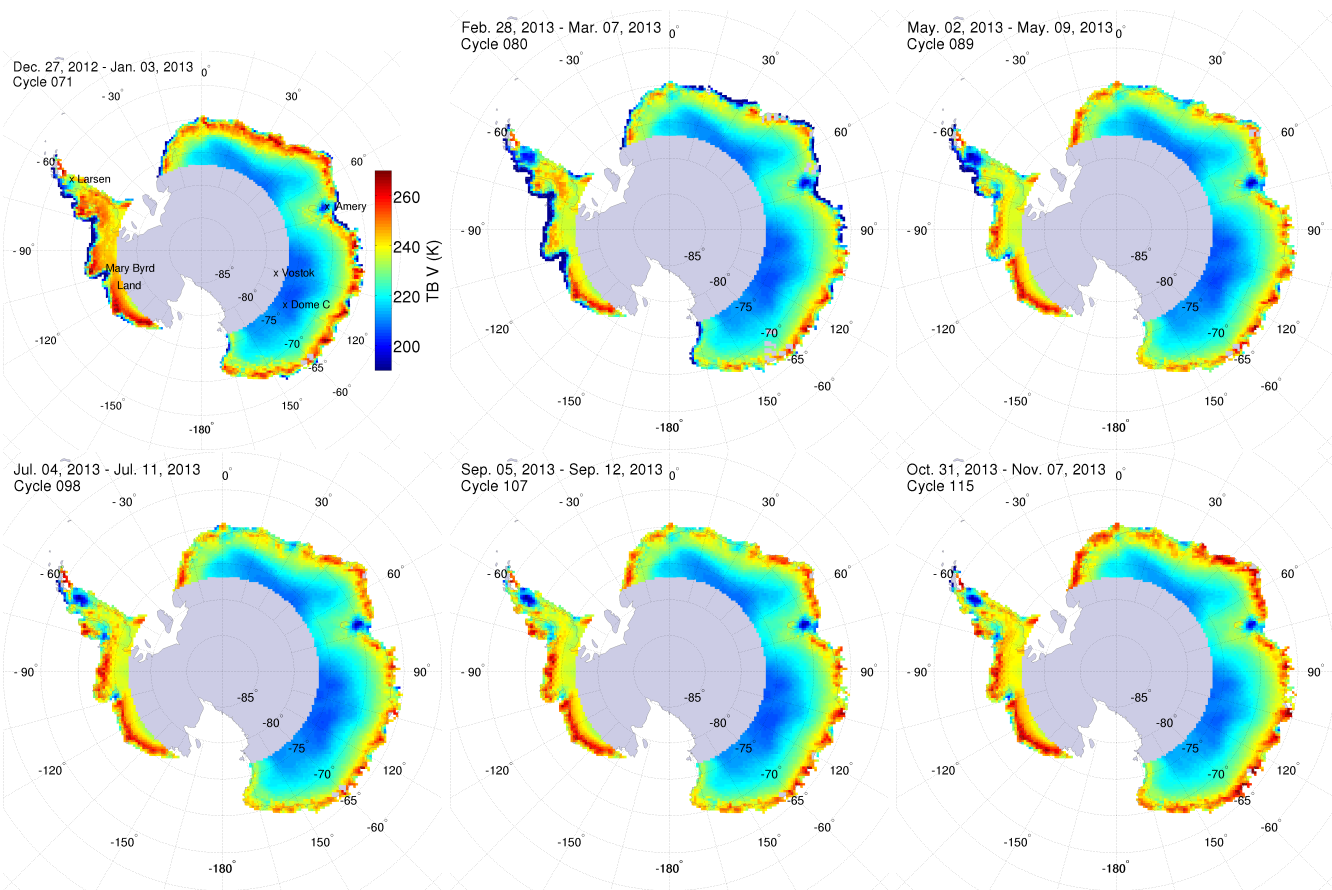

Fig. 5. Maps of TB (radiometer 3) at V polarization (in K) over the AIS every two months in 2013. Grid cells with land fraction less than 0.25 were masked.

periphery. Low TBs $(<200 \mathrm{~K})$ observed at V polarization with radiometer 3 in January and February in the continent periphery are due to the presence of the surrounding sea-icefree ocean (Fig. 5). This effect is only visible on a narrow band of latitudes. Slightly farther inland, there is another narrow band of latitudes with very high TBs $(250-265 \mathrm{~K})$ year round. The spatial extent of these high TBs progresses inland as snow is melting, and reaches its maximum in January.

Low-elevation regions experiencing seasonal melt events have a different passive microwave signature than the drysnow zone at higher elevations. As described in Sect. 3.1 for observations over the GIS, TB time series in the melt zone are characterized by sharp TB variations due to the presence of liquid water. Once the liquid water content decreases, TB decreases too. Depending on the intensity of the melt event, snow properties (such as density) may significantly change, which will modify the microwave emission. When assuming a specular reflection, reflection coefficient of dry snow depends on permittivity values (i.e., the real part of the dielectric constant), which in turn mostly depends on density. Thus, for observations over dry snow, density at the air-snow interface as well as vertical density variation within the firn/snow controls in part the difference between the vertical and horizontal polarizations.

The lowest TBs not contaminated by sea-ice-free ocean are located on the high-elevation domes of the Antarctic plateau. The lowest mean-annual TBs of the Plateau are located at both polarizations in grid cells within or adjacent to the Vostok Lake $\left(76.396^{\circ} \mathrm{S}, 105.852^{\circ} \mathrm{E}\right)$. This suggest that the radiometrically cold lake and/or the particular ice properties over the lake influence the L-band observations. There is also an obvious contrast between the Antarctic plateau and the West AIS (WAIS). The Plateau has higher elevations, lower snow accumulations, no melt events, and thus lower TB than Mary Byrd land (Fig. 5). Standard deviations of TBs observed at $\mathrm{V}$ polarization by radiometer 3 during one cycle in winter are presented in Fig. 2. Several previous studies discuss these spatial distributions of microwave observations at higher frequencies and their correlation with geophysical properties (e.g., Long and Drinkwater, 2000; Schneider and Steig, 2002; Schneider et al., 2004; Picard et al., 2009; Brucker et al., 2010), which are also evident at $\mathrm{L}$ band.

Strong and direct interactions between ice sheets and ocean occur under ice shelves. The Amery ice shelf and ice shelves in the Antarctic Peninsula (e.g., Larsen C located $67.5^{\circ} \mathrm{S}, 62.5^{\circ} \mathrm{W}$ ) are characterized by low-winter TBs (Fig. 5). This suggests that Aquarius observations could be analyzed in these regions to study the relationship between L-band TBs and ice shelf properties (e.g., thickness). Future studies could also investigate the different processes that can operate at the ice-shelf base (e.g., refreezing, or melting releasing fresher water initiating deep water formation).

Considering one weekly gridded TB data set in winter (July) and in summer (January), the ranges of TB for the whole observed AIS are 206-270 K and 178-250 K at V and $\mathrm{H}$ polarizations, respectively (Fig. 6). At both polarizations, 

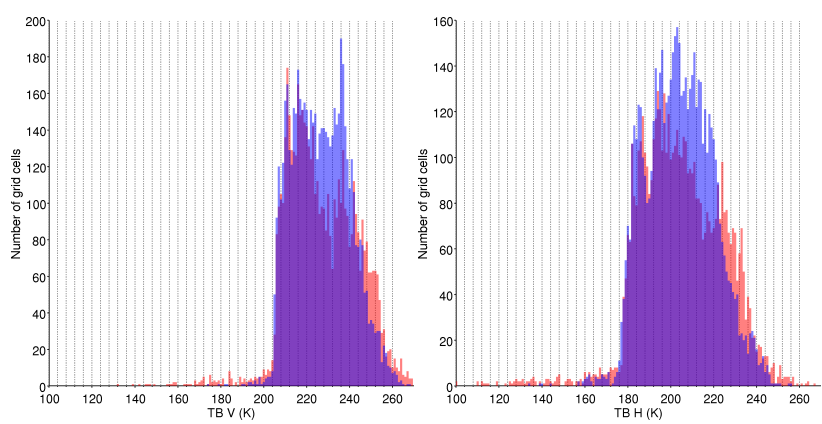

Fig. 6. Distributions of TB V (left) and TB H (right) observed over the AIS using radiometer 3 during the first week of January 2013 (red) and July 2013 (blue).

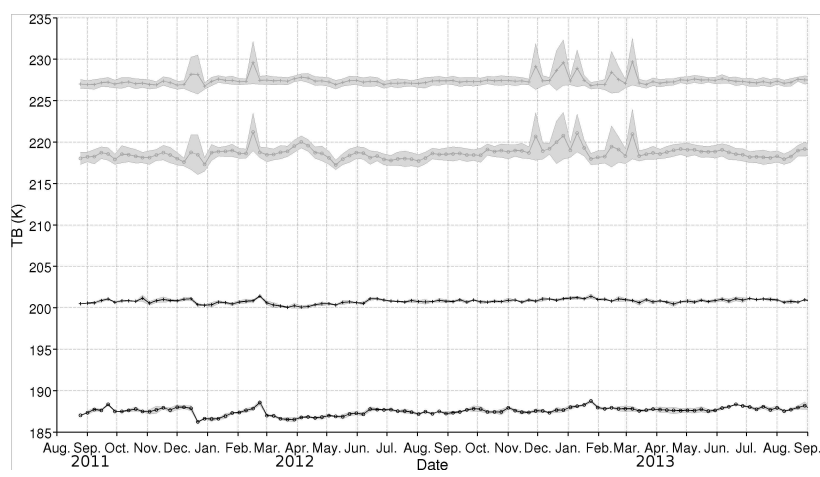

Fig. 7. Time series $\mathrm{TB}$ (radiometer 1$)$ at $\mathrm{V}(+)$ and $\mathrm{H}(\mathrm{o})$ polarizations over Dome C (black), and Mary Byrd land (gray). The gray envelop corresponds to the weekly TB standard deviation.

the range of TB is smaller than that observed over the GIS. Distributions slightly change between the two seasons, with more grid cells having higher TBs in summer, but the ranges do not vary much. As noted earlier, the lowest summer TBs are due to the presence of open water.

The AIS can be used as a target for sensor calibration and intercalibration at $\mathrm{L}$ band. Dome $\mathrm{C}$ is a potential candidate (Drinkwater et al., 2004; Macelloni et al., 2013). Over the period September 2011-September 2013, the mean TBs observed by Aquarius' radiometer 1 at Dome $\mathrm{C}\left(75.1^{\circ} \mathrm{S}\right.$, $123.35^{\circ} \mathrm{E}$, snow accumulation rates of $7.2 \mathrm{~cm} \mathrm{yr}^{-1}$, Urbini et al., 2008) are $202.53 \pm 0.26 \mathrm{~K}$ and $190.12 \pm 0.47 \mathrm{~K}$ at $\mathrm{V}$ and $\mathrm{H}$ polarization, respectively (Fig. 7). These TB standard deviations over the two-year period are low, but they are higher than the radiometers' sensitivity (of $\sim 0.2 \mathrm{~K}$ per $1.44 \mathrm{~s}$ observation sample over perennial dry snow). Over the WAIS, in one grid cell of the Mary Byrd region $\left(79.242^{\circ} \mathrm{S}, 117.718^{\circ} \mathrm{W}\right)$, mean TBs for the same period are $229.68 \pm 0.56 \mathrm{~K}$ and $222.12 \pm 0.74 \mathrm{~K}$ at $\mathrm{V}$ and $\mathrm{H}$ polarization, respectively (Fig. 7). Temporal variability is higher at $\mathrm{H}$ than $\mathrm{V}$ polarization, which was already observed at $\mathrm{L}$ band (Macelloni et al., 2013; Brucker et al., 2014a) and at higher

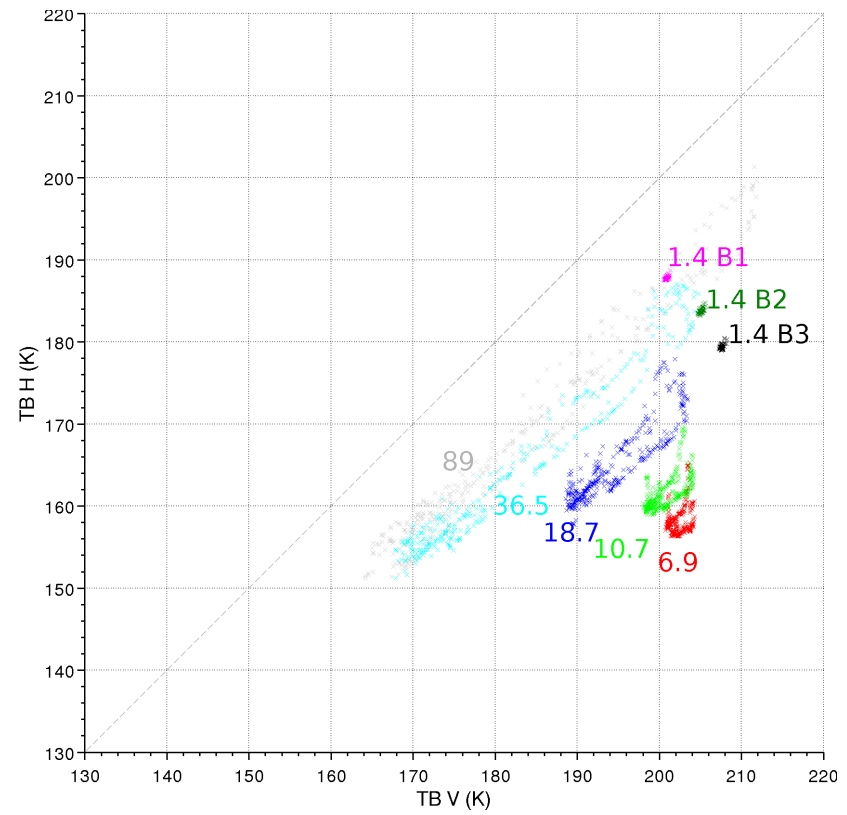

Fig. 8. TB $\mathrm{H}$ as a function of TB V at Dome C, Antarctica, using one year of data; 2013 Aquarius TBs and 2012-2013 AMSR2 TBs were used providing $1.413 \mathrm{GHz}$ data at three different incidence angles, and $6.9,10.7,18.7,36.5$, and $89 \mathrm{GHz}$ data.

microwave frequencies (e.g., Lacroix et al., 2009; Brucker et al., 2011).

TB V increases as the incidence angle increases, whereas TB $\mathrm{H}$ decreases as the incidence angle increases. A detailed discussion of the main temporal TB variations and the effect of snow surface metamorphism on L-band TB observations is presented in Brucker et al. (2014a). The good sensitivity of Aquarius' radiometers made it possible to relate the significant TB variations of up to $2.5 \mathrm{~K}$ observed at Dome $\mathrm{C}$ in summer to changes in snow surface properties. The main TB variations correspond to periods with hoar crystals on the surface. Therefore, in spite of the deep penetration of the L-band radiation, evolutions of the snow properties near the surface, that usually change rapidly and irregularly, influence L-band observations.

Aquarius provides the lowest microwave frequency observations to routinely observe the cryosphere. The next lowest frequencies are available on the Advanced Microwave Scanning Radiometers 2 (AMSR2) in the frequency range 6.9$89 \mathrm{GHz}$. Observations from these sensors at Dome $\mathrm{C}$ are presented for an entire year in a scatter plot of TB $\mathrm{H}$ as a function of TB V (Fig. 8). The amplitude of the variation during the year decreases as frequency decreases (i.e., the width of the ellipse is reduced going from $89 \mathrm{GHz}$ (gray) to $6.9 \mathrm{GHz}$ (red)). This is explained by the lower frequency channels having larger penetration depths, and being thus less sensitive to variations in the temperature profile resulting from solar heating. Considering data from AMSR2 only, observations at $\mathrm{V}$ polarization increase as frequency decreases (from 


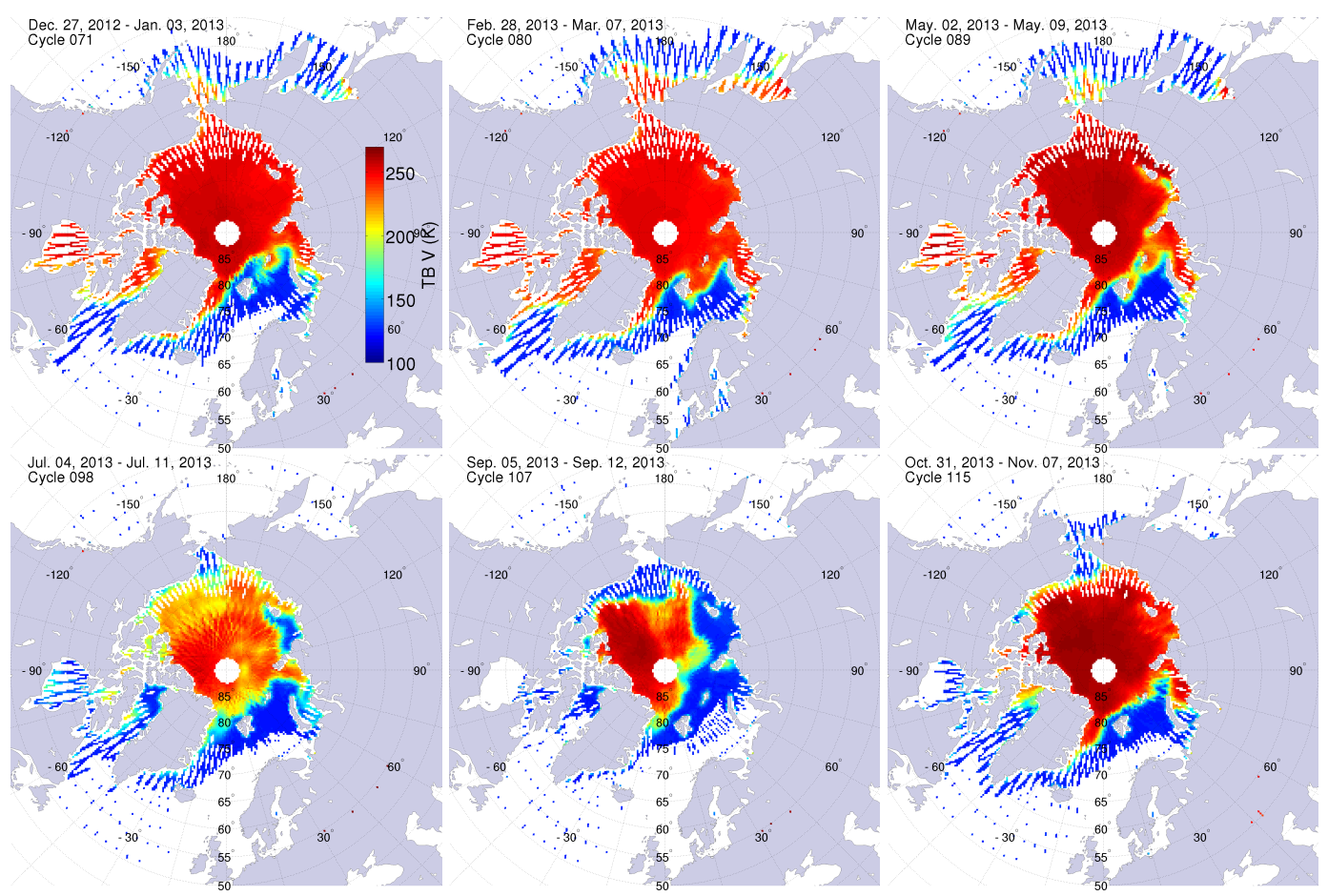

Fig. 9. Maps of TB (radiometer 3) at V polarization over the NH sea ice every two months in 2013. Grid cells where the land fraction was more than 0.25 were masked.

gray to red), and observations at $\mathrm{H}$ polarization decrease as frequency decreases (i.e., each ellipse of AMSR2 TB observations move toward the bottom right corner of Fig. 8 as frequency decreases). Aquarius TB H observations decrease as the incidence angle increases (from radiometer 1 to 3 ; Fig. 8), but they are higher than every annual mean AMSR2 TB H. At both polarizations, Aquarius TB observations are higher than every annual mean AMSR2 TB. Aquarius radiometers operate at lower incidence angles than AMSR2 $\left(<46.3^{\circ}\right.$ vs. $55^{\circ}$ ), which likely explains this behavior. Modeling studies are required to quantify the contributions of the different incidence angles.

\subsection{Sea ice}

In contrast to ice sheets, sea ice is a more dynamic cover. Sea ice forms, grows, and melts according to the seasons, and some sea ice remains year round in certain regions of both the Arctic and Antarctic. Microwave observations depend on the physical (and dielectric) properties of sea ice and its overlying snow cover, both of which evolve with time. The dielectric constant of sea water is very high, and the dielectric loss increases as salinity increases, resulting in large surface reflectivity and low-microwave TB of ice-free ocean (Dinnat et al., 2002). Permittivity and dielectric loss values of sea ice are significantly lower, resulting in higher emissivities. Hence, TB increases as the ice fraction in the field of view increases. Experimental permittivity and dielectric loss at $1 \mathrm{GHz}$ show decreasing values as brine volume decreases (Hallikainen and Winebrenner, 1992). Thus, TB values are higher over multi-year sea ice than seasonal sea ice, as brine is released. Microwave observations also depend on largescale properties of the sea ice cover, whether the sea ice cover is packed or fractured with the presence of leads (open water or new/thin ice).

To present Aquarius weekly polar-gridded TB product over sea ice, all data associated with the presence of sea ice is used. Due to the large-footprint dimensions, this implies that extensive areas with low TBs are also considered (Figs. 9 and 10). For reference, TB V of ice-free ocean is typically less than $\sim 125 \mathrm{~K}$ for radiometer 3 , and less than $\sim 107 \mathrm{~K}$ for radiometer 1 . TBs higher than that are attributed to the presence of sea ice.

In the NH (Fig. 9), TBs are the highest when snow on sea ice is melting (typically in May and June). TBs are lower during the summer months likely when the sea ice cover is more fractured, with leads exposing open sea water. Overall, a similar TB evolution occurs during the year over the $\mathrm{SH}$ sea ice cover (Fig. 10). In Fig. 10, the Ross polynia $\left(75^{\circ} \mathrm{S}\right.$, $178^{\circ}$ E) can be observed in Summer (January-March).

Sea ice can extend to low latitudes (especially in the $\mathrm{SH}$ down to latitudes of $\sim 55^{\circ} \mathrm{S}$ or less). There, Aquarius spatial coverage is significantly reduced. At higher latitudes, where more observations are available, some variability is visible on the weekly TB maps (e.g., distinct lines in July; last panel of Fig. 9). This is related to the fast changing properties of 

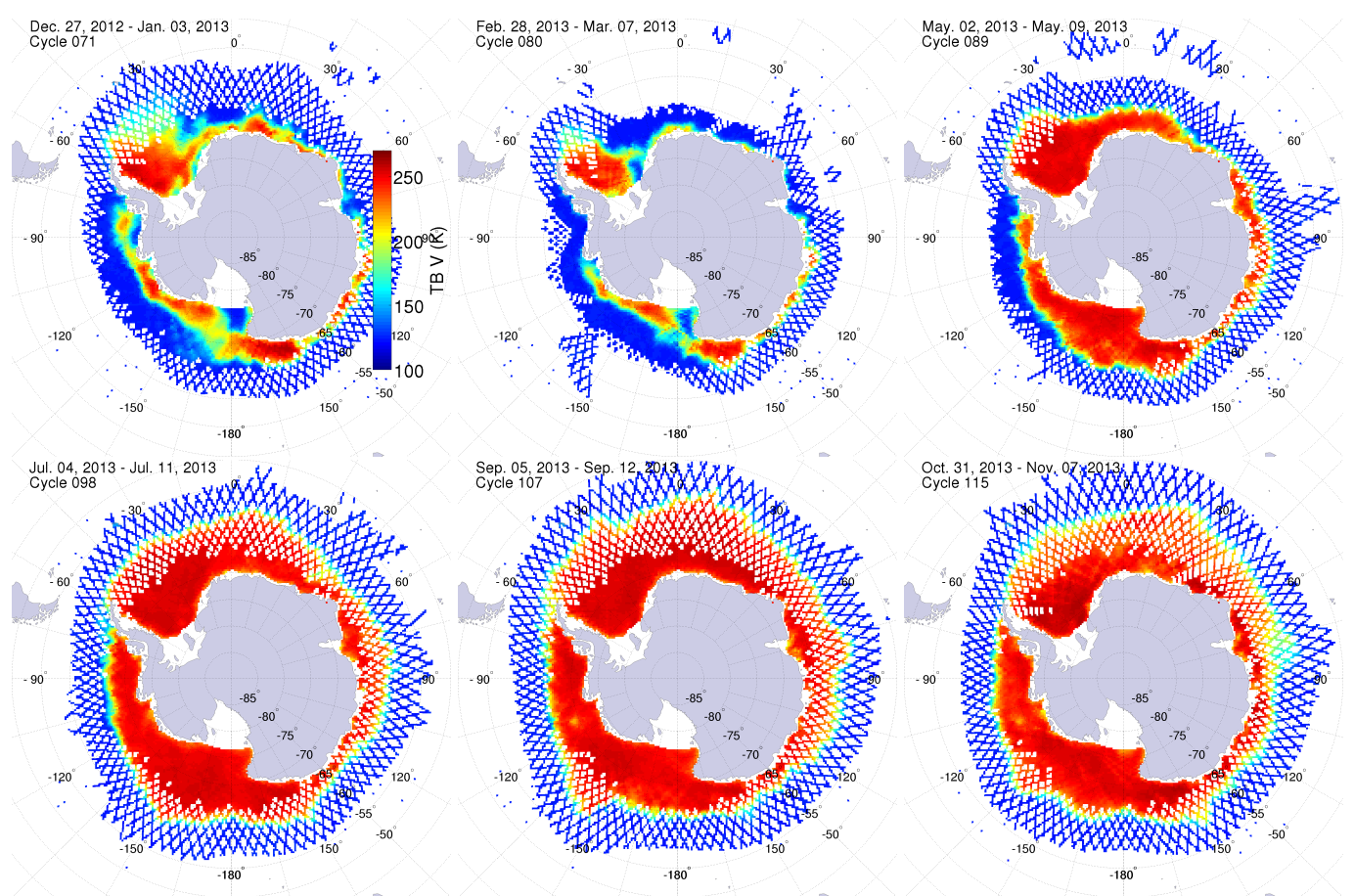

Fig. 10. Maps of TB (radiometer 3) at V polarization over the SH sea ice every two months in 2013. Grid cells where the land fraction was more than 0.25 were masked.

the sea ice cover during the one-week period used to create the gridded product.

To analyze further Aquarius TBs over sea ice, the relationship between ICEF and TB V is analyzed. To that end, swath TBs and ICEFs were used, so that there is no influence of gridding and averaging. Moreover, data in the Ross Sea were used to avoid land contamination. Figure 11 illustrates two important and distinct points. First, it shows the high sensitivity of TB to the presence of sea ice; there is a continuous increase of TB V (radiometer 1) between $\sim 107 \mathrm{~K}$, the level for ice-free water, and $\sim 250 \mathrm{~K}$ which corresponds to a packed Antarctic sea ice cover in winter. Second, Fig. 11 shows that there are numerous low-TB observations $(<110 \mathrm{~K})$ associated with ICEFs ranging from 0 to 0.5 . From our investigations, we noticed that an ICEF of 0.5 raises TB about $70 \mathrm{~K}$ $(85 \mathrm{~K})$ above the nominal ocean TB level at $\mathrm{V}(\mathrm{H})$ polarization using radiometer 1 . ICEF comes from estimated sea ice concentration integrated over the sensor's field of view and weighted by the antenna gain patterns. For the data with a surprisingly low TB, it is very likely that the sea ice concentration estimates (obtained from the analysis by NOAA's Marine Modeling and Analysis Branch, and distributed by the US National Centers for Environmental Prediction (NCEP) as the Global Forecast System (GFS) Global Data Assimilation System (GDAS) sea ice product) are overestimated. Extreme caution should be used over the oceans where there are obvious discrepancies between the ICEF and TB.

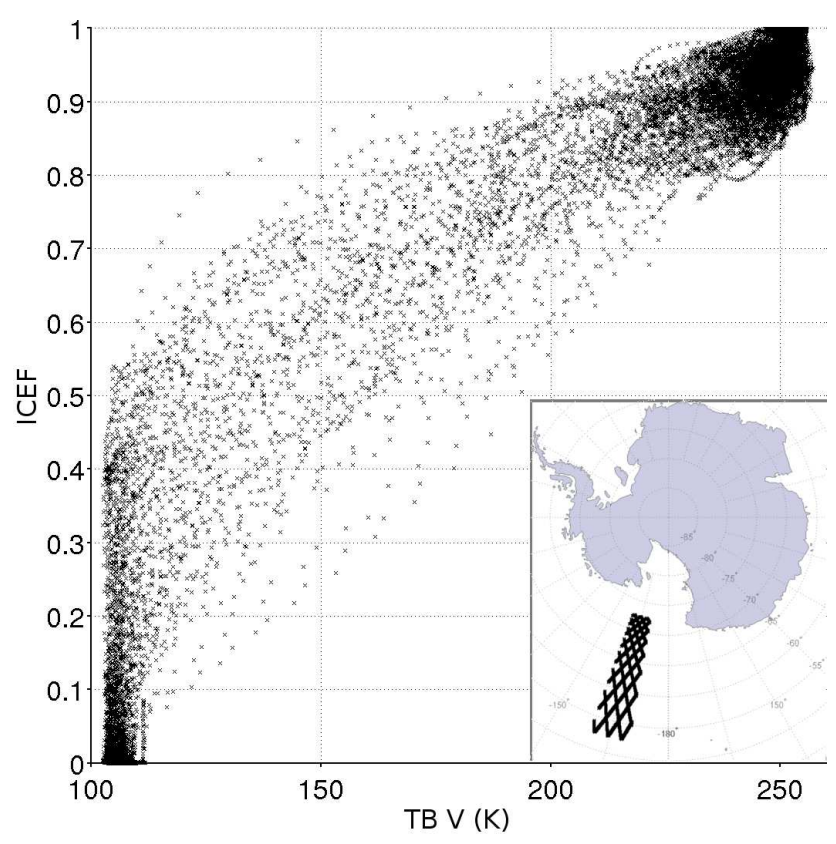

Fig. 11. ICEF as a function of TB V (radiometer 1) in and north of the Ross Sea (see embedded map with the location of the footprint measurements). Swath data from cycle 85 to 105 (i.e., between 4 April 2013 and 29 August 2013. 


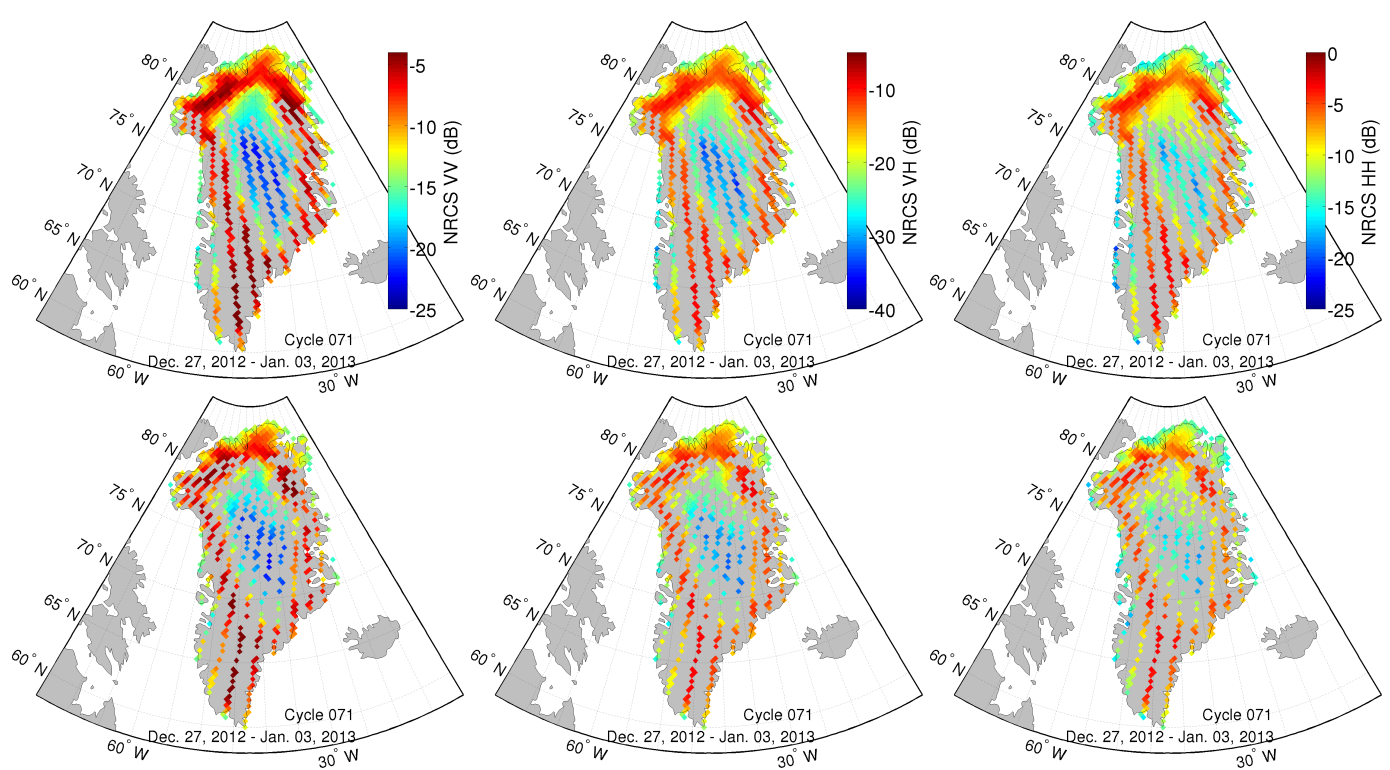

Fig. 12. NRCS (beam 3) at VV (left panels), VH (middle panels), and at HH (right panels) recorded over the GIS during the cycle 72 (310 January 2013) and during ascending orbits (first row), and descending orbits (second row). Grid cells where the land fraction was less than 0.25 were masked.

Studies carried out with SMOS observations show that the L-band TB contains information about thin sea ice thickness (e.g., Kaleschke et al., 2010; Huntemann et al., 2014). Since thin ice is fragile, it is associated with a very heterogeneous surface; the Aquarius large-footprint observations will make the retrievals of thin sea ice thickness very challenging, though they may be complementary to CryoSat- 2 sea ice thickness as, for instance, retrieved by Hendricks et al. (2013).

\section{L-band NRCS product analysis over the cryosphere}

While space-borne L-band synthetic aperture radar (SAR) observations have been available since 1992, space-borne L-band scatterometer observations were first collected by Aquarius in 2011. NRCS analysis over the ice sheets was previously studied at $\mathrm{C}$ band and $\mathrm{Ku}$ band (summarized in Massom and Lubin, 2006). In this section, NRCS observations are presented at the three different polarizations $(\mathrm{VV}$, $\mathrm{VH}$, and $\mathrm{HH}$ ) that could be used to infer snow/ice and surface properties over ice sheets and sea ice.

\subsection{Ice sheets}

Over the GIS, the weekly gridded product provides full spatial coverage of the northern portion of the ice sheet (latitudes higher than $77^{\circ} \mathrm{N}$ ). As with the radiometer, the amount of valid data considered in the weekly gridded product is lower for the descending orbits than the ascending orbits due to the RFI contamination (Fig. 1 in Brucker et al., 2014b).
The different polarizations contain information on the structural characteristics of the ice/firn/snow medium and its surface. NRCS values recorded during the first week of January, 2013, over the GIS show similar patterns at the three polarizations (Fig. 12, first row) and similar patterns between the ascending and descending orbit observations (Fig. 12, first row vs. second row), though small differences in intensity exist. Overall, NRCS values decrease (i.e., become more negative) from the coast toward the highest elevations of the GIS. At higher frequencies, the spatial distribution of NRCS was correlated with the wet snow zone, the percolation zone, and the dry-snow zone (Long and Drinkwater, 1994). Seasonal variations are observed on the NRCS, but they are small. Long and Drinkwater (1999) provide a detailed analysis of the spatial and temporal variations of the NRCS over the different zones of the GIS using Ku-band observations, and the relationship with snow properties. Similar processes may be related to the L-band NRCS observations.

Over the AIS (Fig. 13), the main patterns are also similar at all three polarizations. However, NRCS recorded during ascending and descending orbits are significantly different. Differences between orbit types are visible across the ice sheet, but predominantly in East Antarctica. For instance, differences are easily identified in the Dronning Maud Land sector $\left(20^{\circ} \mathrm{W}-45^{\circ} \mathrm{E}\right)$, in the Victoria Land sector $\left(140-160^{\circ} \mathrm{E}\right)$, and in between (e.g., $\left.75-105^{\circ} \mathrm{E}\right)$. The linear correlation coefficient between NRCS co-polarized (VV and $\mathrm{HH}$ ) observations of the ascending and descending orbits for this first week of July, 2013, is weak (0.510.61 ; Table 1). NRCS observations at the cross-polarization VH have a stronger correlation coefficient between the two 


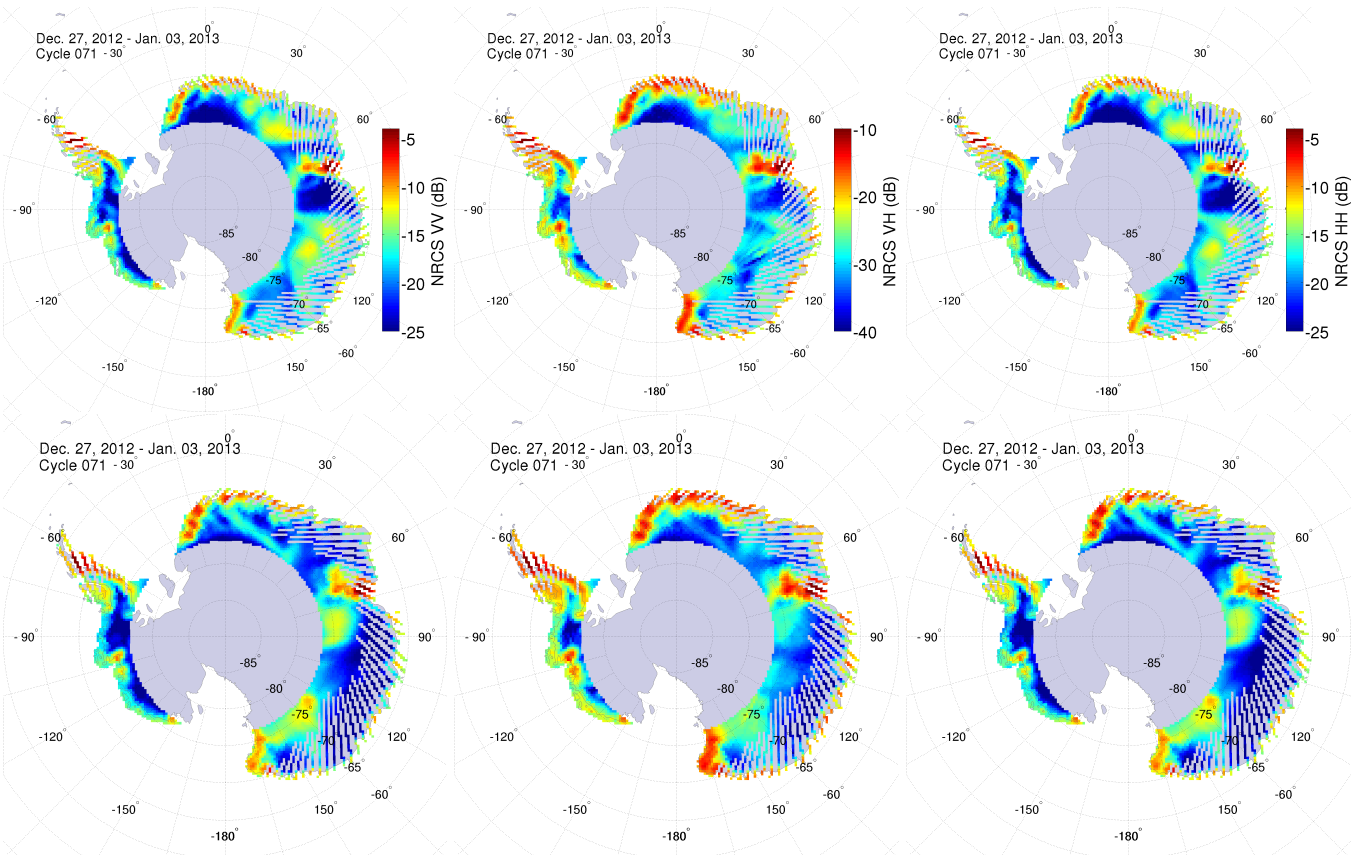

Fig. 13. NRCS (beam 3) at VV (left panels), VH (middle panels), and at HH (right panels) recorded over the AIS during the cycle 98 (411 July 2013), and during ascending orbits (first row) and descending orbits (second row). Grid cells where the land fraction was less than 0.25 were masked.

Table 1. Linear correlation coefficients of the weekly gridded NRCS observations made during the ascending and descending orbits over the AIS during the first week of July 2013 (cycle 98).

\begin{tabular}{cccc}
\hline & Beam 1 & Beam 2 & Beam 3 \\
\hline VV & 0.519 & 0.608 & 0.526 \\
VH & 0.813 & 0.868 & 0.884 \\
HH & 0.510 & 0.625 & 0.569 \\
\hline
\end{tabular}

orbit types (0.81-0.88; Table 1$)$. These values illustrate the importance of distinguishing the ascending and descending orbits when analyzing the NRCS observations, regardless of the polarizations. For a given orbit type, the correlation between the polarizations is the strongest between $\mathrm{VV}$ and $\mathrm{HH}$, and increases as the incidence angles increases (from 0.991 at $29.2^{\circ}$ to 0.998 at $46.3^{\circ}$ ).

At the three polarizations, NRCS observations reveal interesting differences between the two sides of the western Antarctic ice divide. On the Antarctic Peninsula side, where snow accumulation is high, low-NRCS values are observed. On the Ross ice shelf side, where snow accumulation is lower, NRCS values are higher.

\subsection{Sea Ice}

The large field of view of Aquarius scatterometer in conjunction with the spatial heterogeneity of sea ice make it challenging to attribute the changes in NRCS to specific geo- physical properties. At $\mathrm{C}$ band, it was shown that the NRCS variation to changes in ice properties (such as brine volume and wetness) depends on the incidence angle (Scharien et al., 2010). Using brine-snow dielectric parameterizations based on a dielectric mixture model for snow with brine inclusions (Drinkwater and Crocker, 1988), dry-snow permittivity increases as brine volume increases, temperature increases, and density increases. Brine volume has the largest influence on the permittivity of dry snow.

NRCS observations over sea ice are only presented at VV polarization using beam 3 (Fig. 14). The lack of observations in the Beaufort sea (North of Alaska) results from the RFI contamination (Brucker et al., 2014b). Additionally, since only ascending orbits were considered, the spatial coverage is sparse in all Arctic seas; only the central Arctic Ocean is fully monitored. There is a strong seasonal cycle of NRCS, and in the $\mathrm{NH}, \mathrm{NRCS}$ are the lowest (about $-20 \mathrm{~dB}$ ) when the sea ice cover is packed and snow covered. NRCS values increase in summer and reach their maximum (about $-12 \mathrm{~dB}$ ) in September/October before the snow accumulates. In winter, sea ice north of Greenland and the Canadian Archipelago have a higher NRCS (about $-18 \mathrm{~dB}$ vs. $-20 \mathrm{~dB}$ or lower elsewhere). These higher values correspond to a region of older and thicker sea ice with less brine, where roughness of each interface within the $3 \mathrm{~dB}$ footprint can be large compared to the wavelength $(21 \mathrm{~cm})$.

The strong seasonal cycle also exists over Antarctic sea ice (Fig. 15). It is most visible in January-March, when summer 


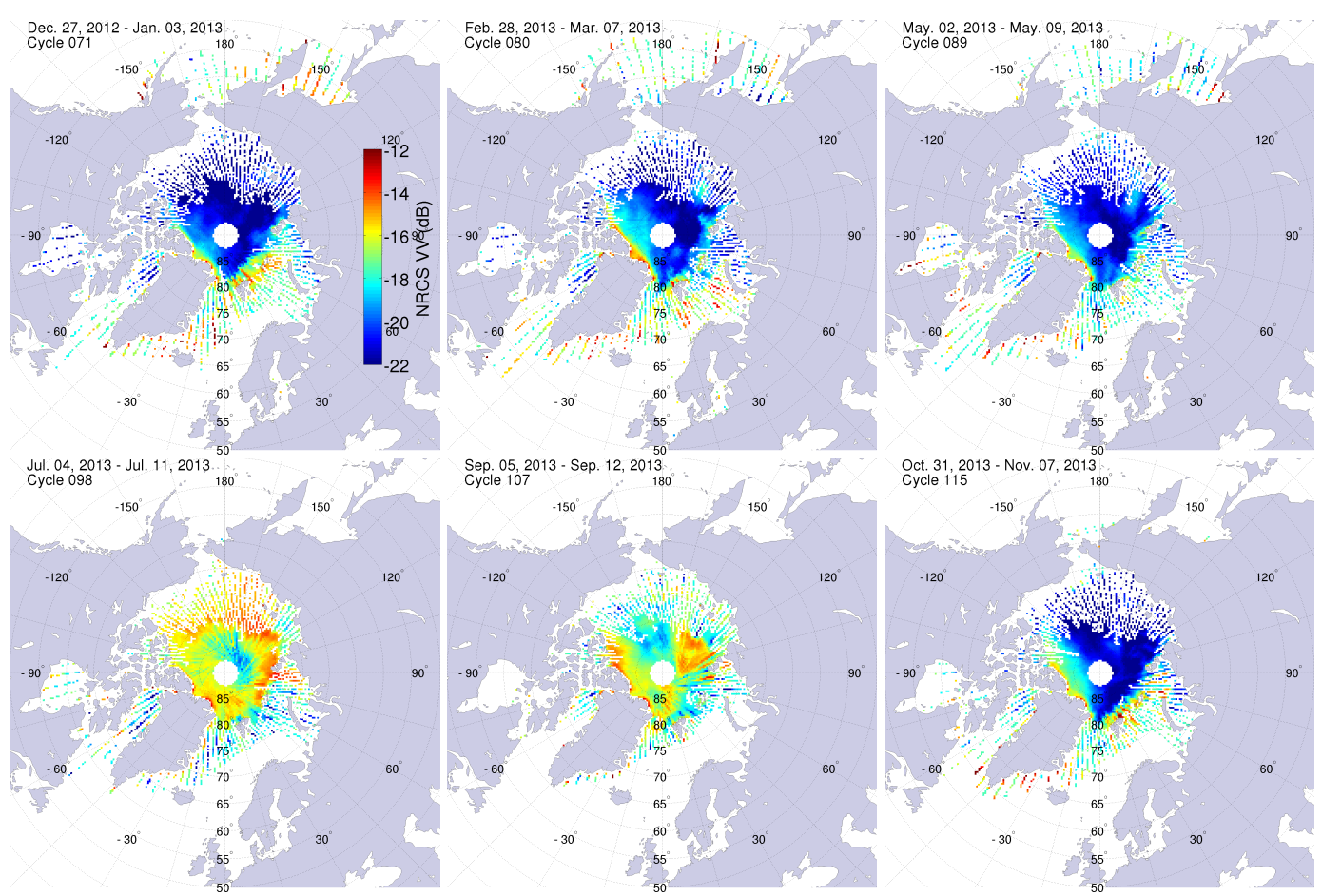

Fig. 14. Maps of beam 3 NRCS VV over the NH sea ice every two months in 2013. Grid cells where the land fraction was more than 0.25 were masked.
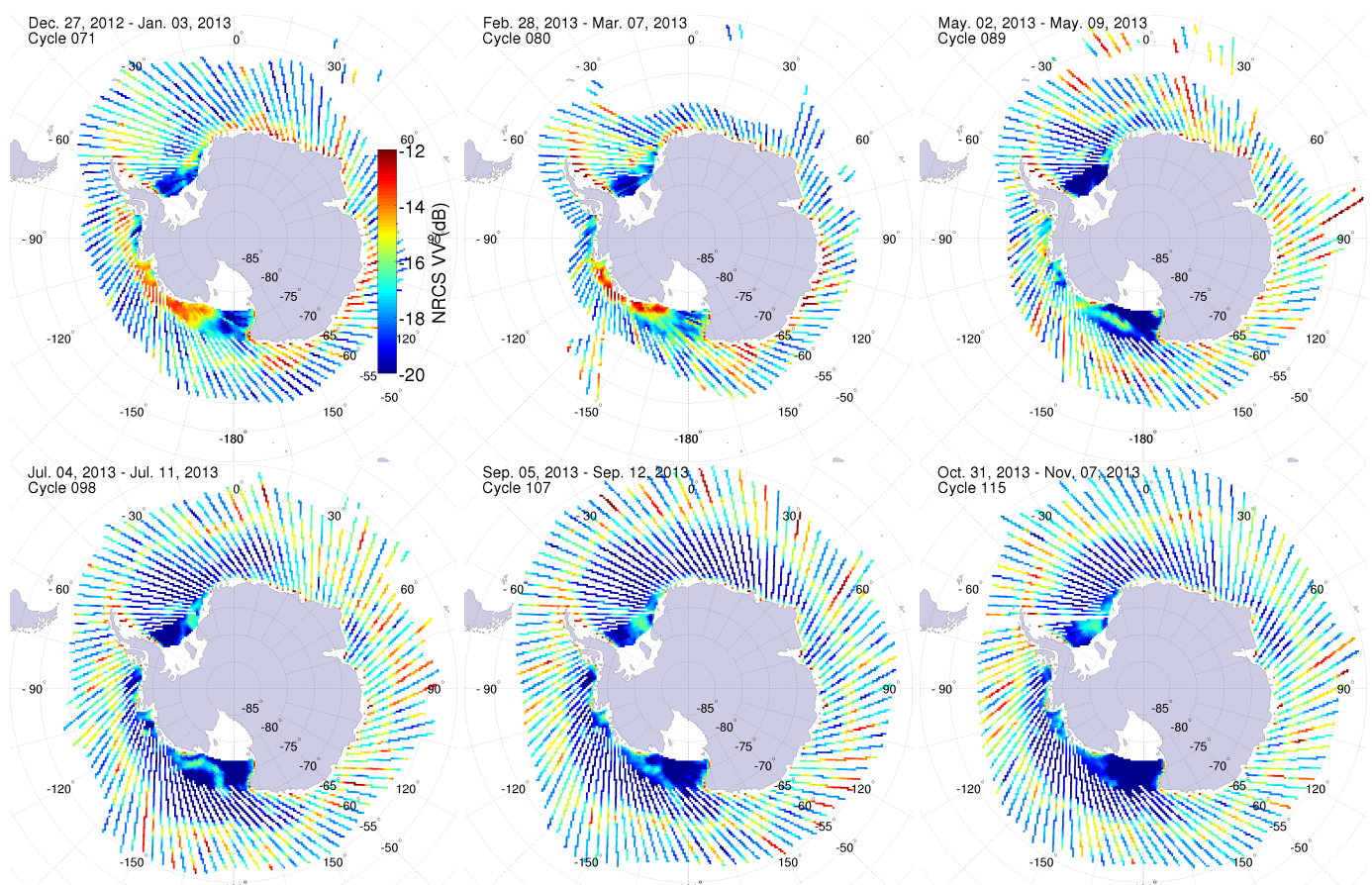

$.180^{\circ}$

$-180^{\circ}$

Fig. 15. Maps of beam 3 NRCS VV over the SH sea ice every two months in 2013. Grid cells where the land fraction was more than 0.25 were masked. 


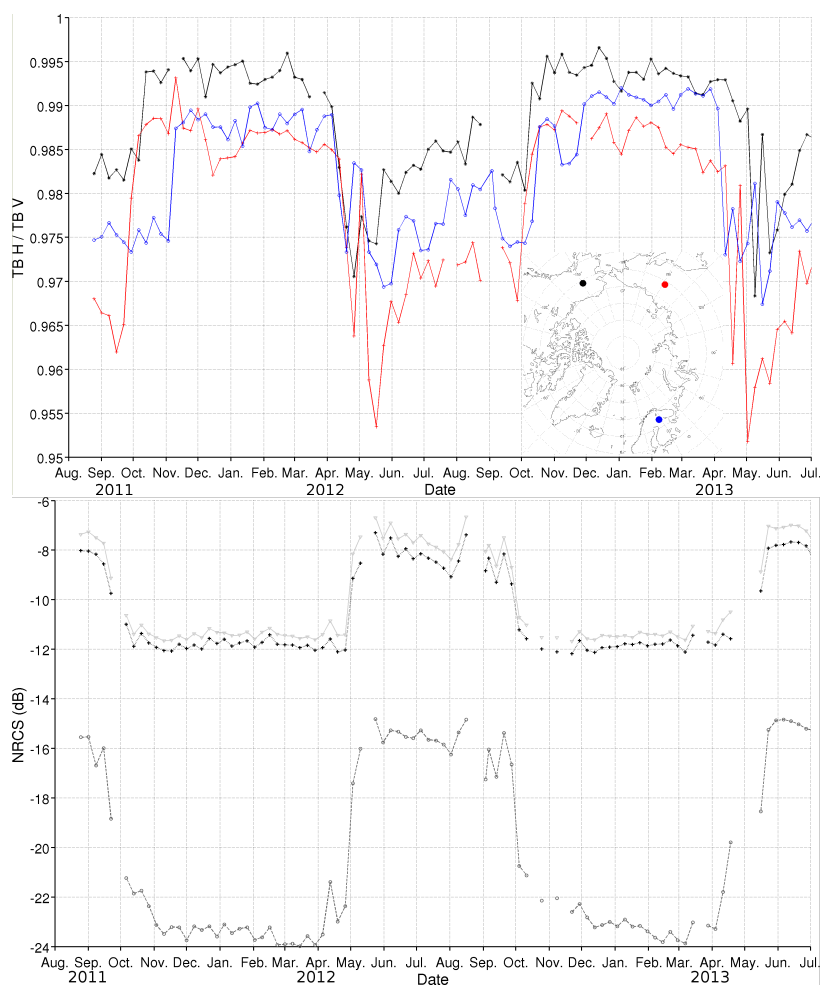

Fig. 16. (Top) time series of the $\mathrm{TB} H / \mathrm{V}$ ratio in three locations: North America (Alaska, USA), $66^{\circ} \mathrm{N}, 150^{\circ} \mathrm{W}$ (black *); Northern Europe (Finland), 67.5 $\mathrm{N}, 29^{\circ} \mathrm{E}$ (blue o); and Asia (Russia), $66^{\circ} \mathrm{N}$, $149.5^{\circ} \mathrm{E}($ red + ). (Bottom) time series of NRCS at (from top to bottom) $\mathrm{HH}$ (continuous line, downward triangles), VV (dotted line, plus symbols), and VH (dashed line, circles) for the location in Asia.

sea ice remains. The very low-NRCS values far from the Antarctic coast in summer are characteristics of open water. As noted in Sect. 3.3 (and Fig. 11), it is very likely that the NCEP GSF GDAS sea ice concentration overestimated the presence of ice. During the winter months, NRCS values over Antarctic sea ice shows a transition ("bright NRCS ring") from the packed sea ice to lower ICEF (Fig. 15). The transition corresponds roughly to an ICEF contour of $0.3-0.4$.

\section{L-band remote sensing of land}

The detection and mapping of frozen soils can be inferred using passive (e.g., Rautiainen et al., 2012) and active (e.g., McDonald et al., 2012) L-band observations. For a given frequency, polarization, and incidence angle, the TB of bare soil is a function of physical temperature and soil moisture. From a theoretical standpoint, Mironov et al. (2013) investigated the possibility of retrieving both the surface temperature and the temperature gradient of the Arctic tundra soil (active layer) from L-band TB. Simulations of refractive index and normalized attenuation coefficient for different soil temperature and moisture levels reveal a noticeable variation as soil temperature becomes positive (Mironov et al., 2013). This variation leads to an increase in TB and allows the determination of soil physical state using L-band TB observations.

To highlight the potential of the weekly gridded products for the monitoring of frozen soils, a two-year time series was extracted from the TB and NRCS data sets in three locations over sub-Arctic environments (in North America, Europe, and Asia). In these regions, seasonal snow is present and frozen soil/permafrost may exist (Brown et al., 2001). The ratio TB $\mathrm{H}$ over $\mathrm{TB} \mathrm{V}(\mathrm{TB} \mathrm{H} / \mathrm{V})$ increases in fall, remains high during the entire winter, and decreases in spring (Fig. 16, top), typical of soil physical state change.

The time series of NRCS in the Asian location also show very distinct values in winter vs. summer (Fig. 16, bottom). At the three polarizations (VV, VH, and $\mathrm{HH}$ ), NRCS are low during the winter months. These time series show information contained in both the passive and active L-band data sets are related to the soil physical state and its surface, and require additional research.

\section{L-band remote sensing of SSS}

Ocean salinity and temperature differences drive thermohaline circulations, and play a key role in the ocean-atmosphere coupling. The strong and direct interactions between ocean and the cryosphere (primarily with sea ice and ice shelves) also contribute to the thermohaline circulation (e.g., Rudels, 1995; Dickson et al., 2008). The weekly gridded product of SSS enables the monitoring of SSS changes in the polar regions, and possibly freshening resulting from the melting cryosphere. However, while the algorithm used in the Aquarius Level 2 processing for retrieving SSS performs well in the tropics and mid-latitudes (warm) oceans (Lagerloef et al., 2013), L-band SSS retrieval in the polar (cold) oceans is challenging. SSS retrievals have not yet been specifically validated in cold water, and should be used with caution.

Polar ocean waters are cold and L-band observations are less sensitive to salinity in cold waters. In addition, salinity retrieval is less accurate for very rough sea surfaces. For instance, in the Southern Ocean there are strong winds and the oceanic circulation is dominated by the Antarctic circumpolar current, which reduce the quality of the SSS retrievals. Finally, the presence of sea ice and icebergs in the sensors' field of view adds complexity to the monitoring of SSS in the high latitudes. As presented in Sect. 3.3, TB is highly sensitive to ICEF, and there is no correction in the SSS algorithm for the presence of ICEF. The presence of ICEF increases TB (Fig. 11) and, if not identified accurately, is interpreted by the SSS-retrieval algorithm as a decrease of SSS. Therefore, one should be particularly careful when studying SSS in the vicinity of sea ice edge and ice sheet. Put simply, increasing TB due to the presence of ice can appear as erroneous freshening. 


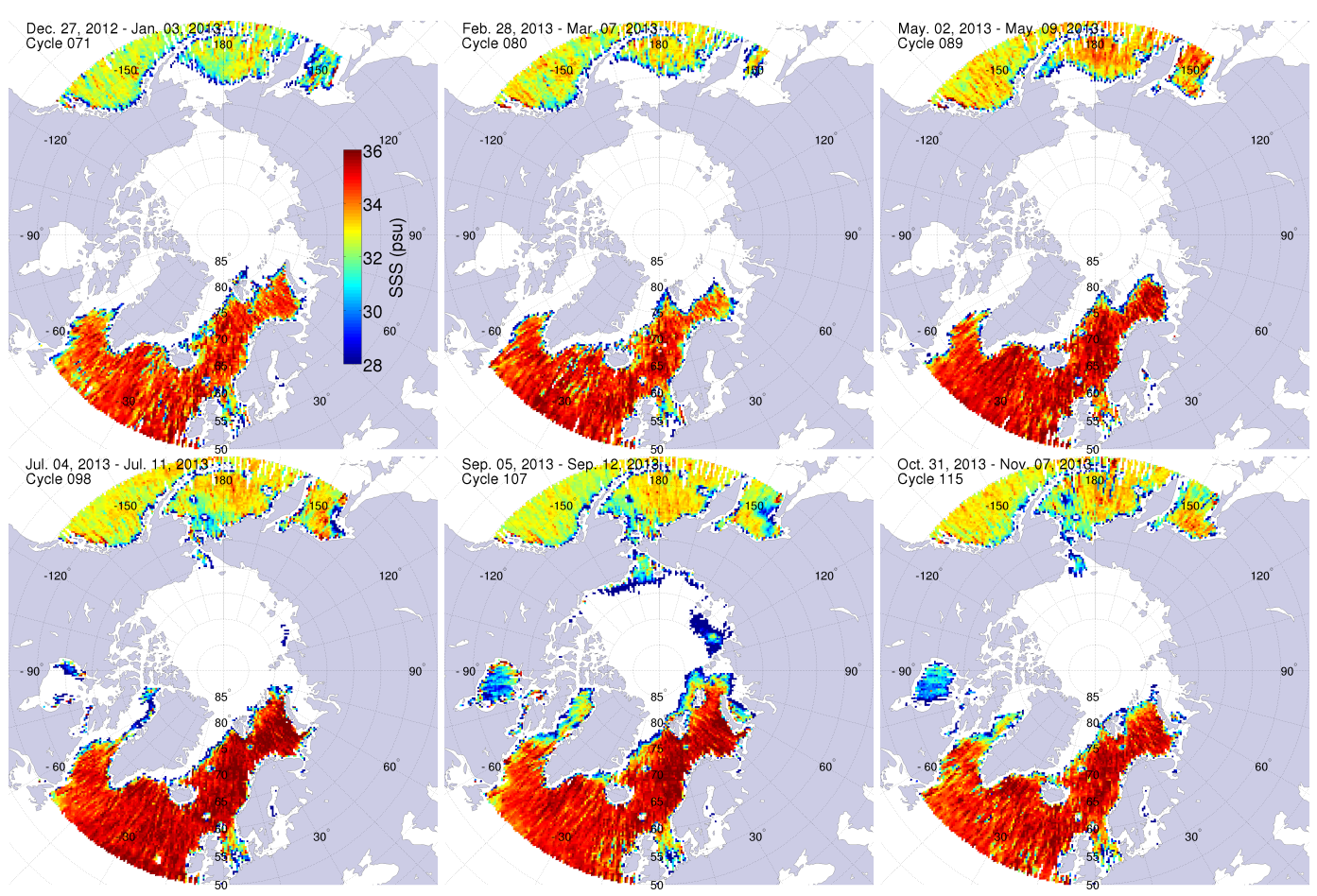

Fig. 17. Maps of SSS3b over the NH high latitudes for cycles every other month in 2013. Grid cells where the land fraction was more than 0.25 were masked.
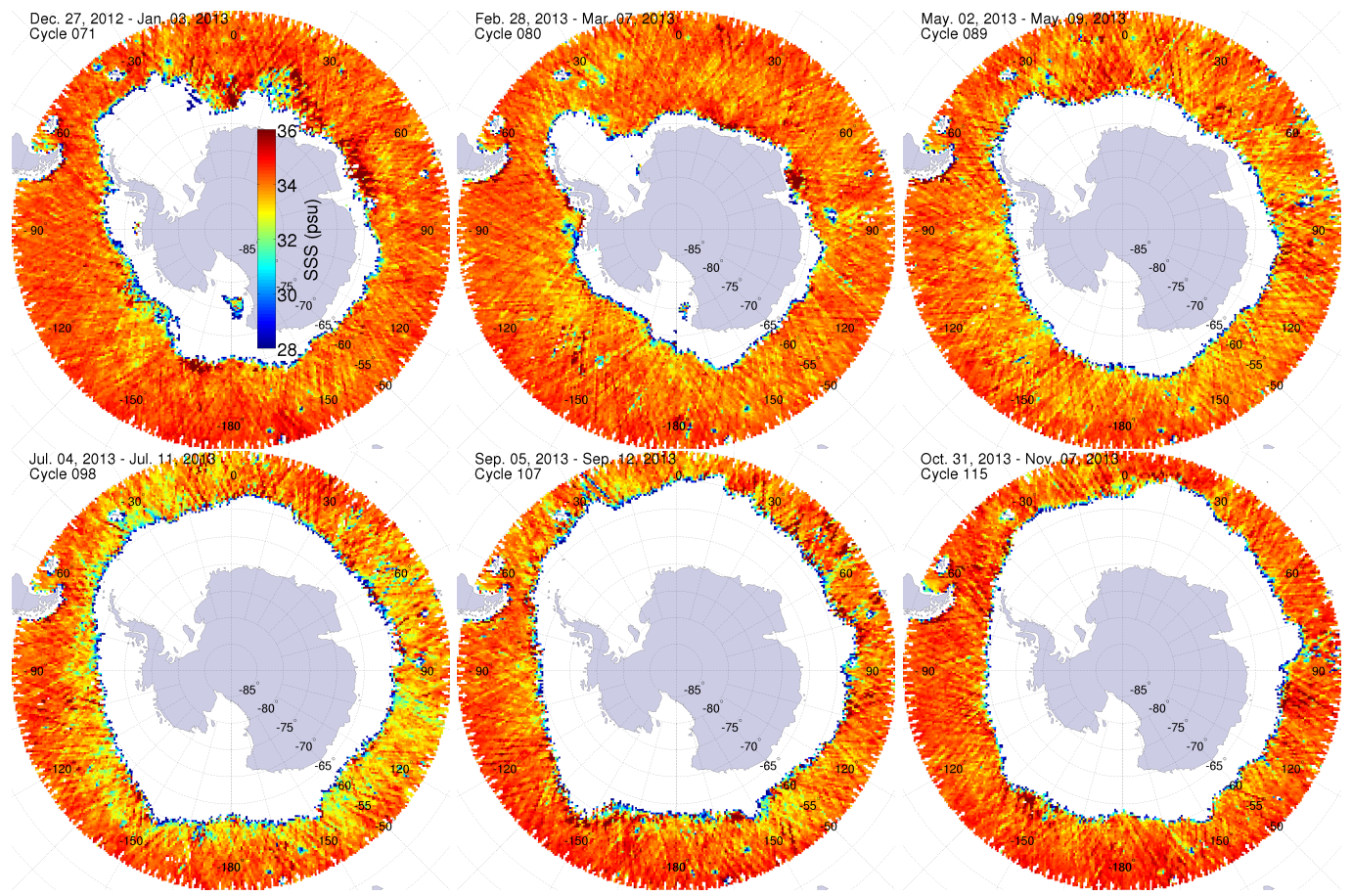

Fig. 18. Maps of SSS3b over the SH high latitudes for cycles every other month in 2013. Grid cells where the land fraction was more than 0.25 were masked. 
When SSS retrievals are possible in the Arctic Ocean (Fig. 17), values are low ( $<30 \mathrm{psu})$. One can also see that blue colors are usually present in the vicinity of the sea ice margin. This may result from sea ice contamination of the Aquarius observations, and does not necessarily reflect a low SSS. These maps also show the significant difference between the Atlantic Ocean (saltier) and the Pacific Ocean (fresher). SSS in the polar regions is expected to vary seasonally as ice freezes up (leaving saltier water in the ocean) and melts (adding fresh water in the ocean).

SSS retrievals in the Southern Ocean (Fig. 18) show a seasonal cycle with lower SSS near the sea ice edge in winter. This again results from sea ice contamination, because in winter during sea ice formation and growth higher SSS are expected. In addition, unrealistic low-SSS retrievals can be associated with the presence of icebergs (e.g., localized SSS lower than 32 psu in January where no land is present nearby). This shows that SSS retrievals should be interpreted with care in polar oceans and polynia until better corrections for sea ice and land contaminations are provided.

\section{Conclusions}

The Aquarius/SAC-D satellite mission collects both passive and active L-band observations which offer new capabilities to study and to monitor the polar regions and the cryosphere. In this paper, we presented weekly gridded products of TB, NRCS, and SSS distributed by the US National Snow and Ice Data Center. While the penetration depth of the L-band radiation in the ice sheet is not well known, Aquarius observations can be useful to retrieve snow and ice properties. These products intend to facilitate the use of combined passive and active L-band observations to study the cryosphere.

The spatial distributions of Aquarius TB and NRCS over the Greenland and Antarctic ice sheet were presented. We showed that the 2012 melt event over the GIS highest elevations impacted the L-band TB, with implications for surface characteristics and mass balance monitoring. NRCS observations recorded during the ascending and descending orbits must be studied separately. Substantial difference exists over sea ice and the AIS due to the anisotropy of the ice covers. NRCS values over Antarctic sea ice show a transition ("bright NRCS ring") from the packed sea ice to lower ICEF with values of $0.3-0.4$. We also showed that both active and passive observations over land present distinct values in summer and winter, depending on the soil physical state. Aquarius $3 \mathrm{~dB}$ footprints are large and make the monitoring of sea ice complex. In both hemispheres, TB over sea ice was the highest when snow on sea ice melts, and the lowest in summer. Studying the surface ocean freshening resulting from ice sheet or sea ice melting is challenging. The sensitivity of the Aquarius SSS retrievals is degraded in cold waters, with sea ice and icebergs in the field of view, and rough ocean surfaces are common. The products TB, NRCS, and SSS may be used for improving our understanding of low-microwave frequency observations, and for the development of new or refined algorithms.

Acknowledgements. This research was funded by the NASA Scientific Innovation Fund. We acknowledge PO.DAAC for distributing the Level 2 Aquarius data (version 2.0) and NSIDC for archiving and distributing the weekly gridded products presented in this paper. We also acknowledge A. Decharon and L. Taylor (University of Maine, School of Marine Sciences) for hosting the visualization of the weekly gridded products of brightness temperature and sea surface salinity on the Aquarius Education \& Public Outreach website (http://aquarius.umaine.edu/cgi/gal_latitudes_tbv.htm and http://aquarius.umaine.edu/cgi/gal_latitudes_sss.htm, respectively). Finally, we acknowledge the reviewers for their useful suggestions.

Edited by: L. Kaleschke

\section{References}

Abdalati, W. and Steffen, K.: Accumulation and hoar effects on microwave emission on the Greenland ice-sheet dry-snow zones, J. Glaciol., 44, 523-531, 1998.

Brodzik, M. J., Billingsley, B., Haran, T., Raup, B., and Savoie, M. H.: EASE-Grid 2.0: Incremental but Significant Improvements for Earth-Gridded Data Sets, ISPRS Int. J. Geo-Inf., 1, 32-45, doi:10.3390/ijgi1010032, 2012.

Brown, J., Ferrians, O., Heginbottom, J. J., and Melnikov, E.: Circum-arctic map of permafrost and ground ice conditions, Tech. rep., National Snow and Ice Data Center, Boulder, CO, 2001.

Brucker, L., Picard, G., and Fily, M.: Snow grain size profiles deduced from microwave snow emissivities in Antarctica, J. Glaciol., 56, 514-526, 2010.

Brucker, L., Picard, G., Arnaud, L., Barnola, J., Schneebeli, M., Brunjail, H., Lefebvre, E., and Fily, M.: Modeling time series of microwave brightness temperature at Dome C, Antarctica, using vertically resolved snow temperature and microstructure measurements, J. Glaciol., 57, 171-182, 2011.

Brucker, L., Dinnat, E. P., Picard, G., and Champollion, N.: Effect of snow surface metamorphism on Aquarius L-band radiometer observations at Dome C, Antarctica, IEEE T. Geosci. Remote, in press, doi:10.1109/TGRS.2014.2312102, 2014a.

Brucker, L., Dinnat, E. P., and Koenig, L. S.: WWeekly gridded Aquarius L-band radiometer/scatterometer observations and salinity retrievals over the polar regions - Part 1: Product description, The Cryosphere, 8, 905-913, doi:10.5194/tc-8-905-2014, 2014b.

Brucker, L., Cavalieri, D. J., Markus, T., and Ivanoff, A.: NASA Team 2 Sea Ice Concentration Retrieval Uncertainty, IEEE T. Geosci. Remote, in press, doi:10.1109/TGRS.2014.2311376, 2014c.

Burgess, E. W., Forster, R. R., Box, J. E., Mosley-Thompson, E., Bromwich, D. H., Bales, R. C., and Smith, L. C.: A spatially calibrated model of annual accumulation rate on the Greenland Ice Sheet (1958-2007), J. Geophys. Res.-Earth, 115, F02004, doi:10.1029/2009JF001293, 2010. 
Dickson, R. R., Meincke, J., and Rhines, P. (Eds.): Arctic-Subarctic Ocean Fluxes, Defining the Role of the Northern Seas in Climate, Springer, the Netherlands, 2008.

Drinkwater, M. R. and Crocker, G. B.: Modelling changes in the dielectric and scattering properties of young snow-covered sea ice at GHz frequencies, J. Glaciol., 34, 274-282, 1988.

Drinkwater, M. R., Floury, N., and Tedesco, M.: L-band ice sheet brightness temperatures at Dome $\mathrm{C}$, Antarctica: spectral emission modelling, temporal stability and impact of the ionosphere., Ann. Glaciol., 39, 391-396, doi:10.3189/172756404781814014, 2004.

Dinnat, E. P., Boutin, J., Caudal, G., Etcheto, J., and Waldteufel, P.: Influence of sea surface emissivity model parameters at L-band for the estimation of salinity, Int. J. Remote Sens., 23, 51175122, doi:10.1080/01431160210163119, 2002.

Hall, D. K., Comiso, J. C., DiGirolamo, N. E., Shuman, C. A., Box, J. E., and Koenig, L. S.: Variability in the surface temperature and melt extent of the Greenland ice sheet from MODIS, Geophys. Res. Lett., 40, 2114-2120, doi:10.1002/grl.50240, 2013.

Hallikainen, M. and Winebrenner, D. P.: The Physical Basis for Sea Ice Remote Sensing, chap. 4, Passive microwave signatures of sea ice, 29-46, American Geophysical Union, Geophysical Monograph, 68, doi:10.1029/GM068p0029, 1992.

Hendricks, S., Ricker, R., and Helm, V.: AWI CryoSat-2 Sea Ice Thickness Data Product, Tech. rep., Alfred Wegener Institute, Bremerhaven, Germany, 2013.

Huntemann, M., Heygster, G., Kaleschke, L., Krumpen, T., Mäkynen, M., and Drusch, M.: Empirical sea ice thickness retrieval during the freeze-up period from SMOS high incident angle observations, The Cryosphere, 8, 439-451, doi:10.5194/tc-8-4392014, 2014.

Kaleschke, L., Maaß, N., Haas, C., Hendricks, S., Heygster, G., and Tonboe, R. T.: A sea-ice thickness retrieval model for $1.4 \mathrm{GHz}$ radiometry and application to airborne measurements over low salinity sea-ice, The Cryosphere, 4, 583-592, doi:10.5194/tc-4583-2010, 2010.

Kaleschke, L., Tian-Kunze, X., Maaß, N., Mäkynen, M., and Drusch, M.: Sea ice thickness retrieval from SMOS brightness temperatures during the Arctic freeze-up period, Geophys. Res. Lett., 39, L05501, doi:10.1029/2012GL050916, 2012.

Lacroix, P., Legresy, B., Remy, F., Blarel, F., Picard, G., and Brucker, L.: Rapid change of snow surface properties at Vostok, East Antarctica, revealed by altimetry and radiometry, Remote Sens. Environ., 113, 2633-2641, doi:10.1016/j.rse.2009.07.019, 2009.

Lagerloef, G., Kao, H.-Y., Meln, O., Hacker, P., Hackert, E., Chao, Y., Hilburn, K., Meissner, T., Yueh, S., Hong, L., and Lee, T.: Aquarius Salinity Validation Analysis, Tech. rep., AQ-014-PS0016, NASA, Pasadena, CA, USA, 2013.

Le Vine, D., Lagerloef, G. S. E., and Torrusio, S.: Aquarius and Remote Sensing of Sea Surface Salinity from Space, Proc. IEEE, 98, 688-703, doi:10.1109/JPROC.2010.2040550, 2010.

Long, D. and Drinkwater, M.: Azimuth variation in microwave scatterometer and radiometer data over Antarctica, IEEE T. Geosci. Remote, 38, 1857-1870, doi:10.1109/36.851769, 2000.

Long, D. G. and Drinkwater, M. R.: Greenland ice-sheet surface properties observed by the Seasat-A scatterometer at enhanced resolution, J. Glaciol., 40, 213-230, 1994.
Long, D. G. and Drinkwater, M. R.: Cryosphere applications of NSCAT data, IEEE T. Geosci. Remote, 37, 1671-1684, doi:10.1109/36.763287, 1999.

Maaß, N., Kaleschke, L., Tian-Kunze, X., and Drusch, M.: Snow thickness retrieval over thick Arctic sea ice using SMOS satellite data, The Cryosphere, 7, 1971-1989, doi:10.5194/tc-7-19712013, 2014.

Macelloni, G., Brogioni, M., Pettinato, S., Zasso, R., Crepaz, A., Zaccaria, J., Padovan, B., and Drinkwater, M.: Ground-Based L-Band Emission Measurements at Dome-C Antarctica: The DOMEX-2 Experiment, IEEE T. Geosci. Remote, 51, 47184730, 2013.

Magand, O., Picard, G., Brucker, L., Fily, M., and Genthon, C.: Snow melting bias in microwave mapping of Antarctic snow accumulation, The Cryosphere, 2, 109-115, doi:10.5194/tc-2-1092008, 2008.

Massom, R. A. and Lubin, D.: Polar Remote Sensing, Volume II: Ice Sheet, Springer/Praxis, Chichester, UK, and Berlin, Germany, 426 pp., 2006.

McDonald, K., Podest, E., Dunbar, S., Njoku, E., and Kimball, J.: Algorithm Theoretical Basis Document SMAP Level 3 Radar Freeze/Thaw Data Product (L3_FT_A), Tech. Rep. Initial Release, v.1, Jet Propulsion Laboratory, California Institute of Technology, Pasadena, CA, 2012.

Mironov, V., Muzalevskiy, K., and Savin, I.: Retrieving Temperature Gradient in Frozen Active Layer of Arctic Tundra Soils From Radiothermal Observations in L -Band - Theoretical Modeling, IEEE J. Sel. Top. Appl., 6, 1781-1785, doi:10.1109/JSTARS.2013.2262108, 2013.

Mätzler, C.: Applications of the interaction of microwaves with the natural snow cover, Remote Sensing Reviews, 2, 259-387, 1987.

Picard, G., Brucker, L., Fily, M., Gallée, H., and Krinner, G.: Modeling time series of microwave brightness temperature in Antarctica, J. Glaciol., 55, 537-551, doi:10.3189/002214309788816678, 2009.

Picard, G., Domine, F., Krinner, G., Arnaud, L., and Lefebvre, E.: Inhibition of the positive snow-albedo feedback by precipitation in interior Antarctica, Nature Climate Change, 2, 795-798, doi:10.1038/nclimate1590, 2012.

Rautiainen, K., Lemmetyinen, J., Pulliainen, J., Vehvilainen, J., Drusch, M., Kontu, A., Kainulainen, J., and Seppanen, J.: L-Band Radiometer Observations of Soil Processes in Boreal and Subarctic Environments, IEEE T. Geosci. Remote, 50, 1483-1497, doi:10.1109/TGRS.2011.2167755, 2012.

Rudels, B.: The Thermohaline Circulation of the Arctic Ocean and the Greenland Sea, Philos. T. Roy. Soc. A., 352, 287-299, 1995

Scharien, R. K., Geldsetzer, T., Barber, D. G., Yackel, J. J., and Langlois, A.: Physical, dielectric, and $\mathrm{C}$ band microwave scattering properties of first-year sea ice during advanced melt, J. Geophys. Res.-Oceans, 115, C12026, doi:10.1029/2010JC006257, 2010.

Schneider, D. P. and Steig, E. J.: Spatial and temporal variability of Antarctic ice sheet microwave brightness temperatures, Geophys. Res. Lett., 29, 1964, doi:10.1029/2002GL015490, 2002.

Schneider, D. P., Steig, E. J., and Comiso, J. C.: Recent Climate Variability in Antarctica from Satellite-Derived Temperature Data, J. Climate, 17, 1569-1583, doi:10.1175/15200442(2004)017<1569:RCVIAF>2.0.CO;2, 2004. 
Steffen, K., Box, J. E., and Abdalati, W.: Special Report on Glaciers, Ice Sheets and Volcanoes, trib. to M. Meier, chap. Greenland Climate Network: GC-Net, 98-103, CRREL 96-27, 1996.

Surdyk, S.: Using microwave brightness temperature to detect short-term surface air temperature changes in Antarctica: An analytical approach, Remote Sens. Environ., 80, 256-271, 2002.

Tedesco, M., Abdalati, W., and Zwally, H. J.: Persistent surface snowmelt over Antarctica (1987-2006) from $19.35 \mathrm{GHz}$ brightness temperatures, Geophys. Res. Lett., 34, 18504, doi:10.1029/2007GL031199, 2007.

Tian-Kunze, X., Kaleschke, L., Maaß, N., Mäkynen, M., Serra, N., Drusch, M., and Krumpen, T.: SMOS derived sea ice thickness: algorithm baseline, product specifications and initial verification, The Cryosphere Discuss., 7, 5735-5792, doi:10.5194/tcd7-5735-2013, 2013.

Torinesi, O., Fily, M., and Genthon, C.: Variability and Trends of the Summer Melt Period of Antarctic Ice Margins since 1980 from Microwave Sensors, J. Climate, 16, 1047-1060, doi:10.1175/1520-0442(2003)016<1047:VATOTS>2.0.CO;2, 2003.

Ulaby, F. T., Moore, R. K., and Fung, A. K.: Microwave Remote Sensing: Active and Passive, Vol. III - Volume Scattering and Emission Theory, Advanced Systems and Applications, Artech House, Inc., Dedham, Massachusetts, 1986.
Urbini, S., Frezzotti, M., Gandolfi, S., Vincent, C., Scarchilli, C., Vittuari, L., and Fily, M.: Historical behaviour of Dome $\mathrm{C}$ and Talos Dome (East Antarctica) as investigated by snow accumulation and ice velocity measurements, Global Planet. Change, 60, 576-588, doi:10.1016/j.gloplacha.2007.08.002, 2008.

Utku, C. and Le Vine, D.: Topographic Signatures in Aquarius Radiometer and Scatterometer Response, IEEE T. Geosci. Remote, 52, 4141-4154, doi:10.1109/TGRS.2013.2280015, 2013.

Winebrenner, D. P., Arthern, R. J., and Shuman, C. A.: Mapping Greenland accumulation rates using observations of thermal emission at 4.5-cm wavelength, J. Geophys. Res., 106, 3391933934, doi:10.1029/2001JD900235, 2001.

Yueh, S., Lagerloef, G., Kao, H.-Y., Carey, D., Le Vine, D., Piepmeier, J., Dinnat, E. P., de Matthaeis, P., Hong, L., Utku, C., Ruf, C., Chen, D., Vandemark, D., Jones, L., Hejazin, Y., Brown, S., Misra, S., Neumann, G., Freedman, A., Fore, A., Tang, W., Xu, X., Bindlish, R., Hacker, P., Chao, Y., Wentz, F., Hilburn, K., Meissner, T., and Scott, J.: Aquarius Satellite Salinity Measurements, Aquarius/SACD Science Team Meeting, Buenos Aires, Oral presentation, NASA, 2012.

Zwally, H.: Microwave emissivity and accumulation rate of polar firn, J. Glaciol., 18, 195-214, 1977. 